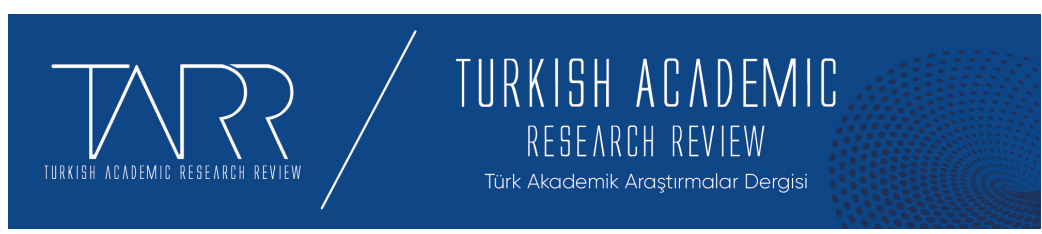

e-ISSN: 2602-2923 Yıl/Year: 2021 Cilt/Volume: 6 Sayı/Issue: 5

\title{
Covid-19 Pandemi Sürecinde Uzaktan Eğitim: Köşe Yazıları Üzerine Bir İnceleme
}

Online Education on the Covid-19 Pandemic Process: A Review on Columns

\section{Mehmet Fatih KARACA - Şirin KARAL TEMÜROĞLU - Güler UZUN}

Dr. Öğr. Üyesi, Tokat Gaziosmanpaşa Üniversitesi Erbaa Meslek Yüksekokulu, Bilgisayar Teknolojileri Bölümü/Assist. Prof. Dr., Tokat Gaziosmanpaşa University, Erbaa Vocational School of Higher Education, Department of Computer Technologies, mehmetfatih.karaca@gop.edu.tr, Orcid ID: https://orcid.org/0000-0002-7612-1437

Dr. Öğr. Üyesi, Tokat Gaziosmanpaşa Üniversitesi Erbaa Sosyal ve Beşeri Bilimler Fakültesi, İletişim ve Tasarımı Bölümü/Assist. Prof. Dr., Tokat Gaziosmanpaşa University, Faculty of Erbaa Social Sciences and Humanities, Department of Communication and Design, sirin.karal@gop.edu.tr, Orcid ID: https://orcid.org/0000-0002-8114-6866

Öğr. Gör., Tokat Gaziosmanpaşa Üniversitesi Erbaa Meslek Yüksekokulu, Görsel-İşitsel Teknikler ve Medya Yapımcılığı Bölümü/Lecturer, Tokat Gaziosmanpaşa University, Erbaa Vocational School of Higher Education, Department of Audio, Visual Techniques and Media Production, guler.uzun@gop.edu.tr, Orcid ID: https://orcid.org/0000-0001-9832-8087

\begin{tabular}{r|l} 
Makale Bilgisi & Article Information \\
Makale Türü - Article Type & Araştırma Makalesi / Research Article \\
Geliş Tarihi - Date Received & 8 Eylül / September 2021 \\
Kabul Tarihi - Date Accepted & 28 Aralık / December 2021 \\
Yayın Tarihi - Date Published & 31 Aralık / December 2021 \\
Yayın Sezonu & Aralık \\
Pub Date Season & December
\end{tabular}

Atıf / Cite as: Karaca, M.F.-Karal Temüroğlu, Ş.-Uzun, G., (2021), Covid-19 Pandemi Sürecinde Uzaktan Eğitim: Köşe Yazıları Üzerine Bir İnceleme/Online Education on the Covid-19 Pandemic Process: A Review on Columns. Turkish Academic Research Review, 6 (5), 1293-1329. Retrieved from https://dergipark.org.tr/tr/pub/tarr/issue/67845/992615

Intihal / Plagiarism: Bu makale, en az iki hakem tarafından incelenmiş ve intihal içermediği teyit edilmiştir. / This article has been reviewed by at least two referees and confirmed to include no plagiarism. https://dergipark.org.tr/tr/pub/tarr

Copyright (C) Published by Mehmet ŞAHIN Since 2016- Akdeniz University, Faculty of Theology, Antalya, 07058 Turkey. All rights reserved.

Turkish Academic Research Review - Türk Akademik Araştırmalar Dergisi 


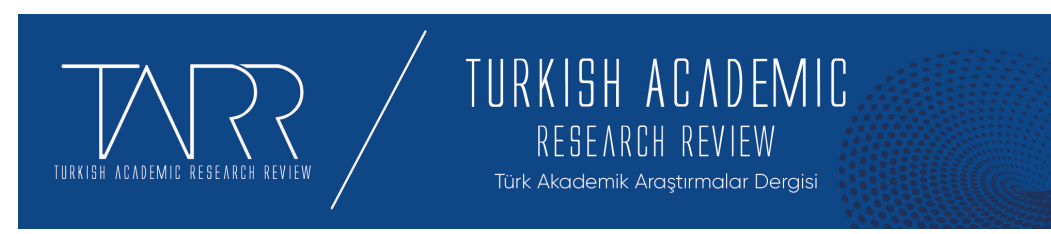

e-ISSN: 2602-2923 Yil/Year: 2021 Cilt/Volume: 6 Sayı/Issue: 5

\section{Covid-19 Pandemi Sürecinde Uzaktan Eğitim: Köşe Yazıları Üzerine Bir İnceleme}

\section{Mehmet Fatih KARACA - Şirin KARAL TEMÜROĞLU - Güler UZUN}

\section{$\ddot{\mathbf{O z}}$}

İlk kez 2019 yılının aralık ayında ortaya çıkan ve kısa sürede dünyayı etkisi altına Covid-19 nedeniyle 11 Mart 2020'de pandemi ilan edilmiştir. Bu süreçte tüm dünyanın en önemli gündemi haline gelen Covid-19 pandemisi, birçok alanla beraber eğitim alanı da etkilemiştir. Covid-19 pandemisi sürecinde salgın seyrine bağlı olarak farklı zamanlarda sosyal izolasyonun sağlanması ve bulaş riskinin azaltılması amacıyla yüz yüze eğitimden uzaktan eğitime geçiş kararları alınmıştır. Fakat uzaktan eğitime geçiş önündeki birtakım engellerin kaldırılması ve sürecin mümkün olduğu kadar az zararla atlatılabilmesi için yetkililer tarafindan ortaya konulan uygulamaların çeşitli yönleriyle ele alınarak tartışıldığı ve ülke gündemi haline geldiği görülmüştür. Pandemi döneminde eğitim-öğretim köşe yazılarına da konu olmuş, köşe yazarları tarafından bu yazılarda uzaktan eğitime ilişkin çeşitli değerlendirmeler yapılmış ve konu birçok yönüyle ele alınmıştır.

$\mathrm{Bu}$ çalışmada, Türkiye'nin tirajı en yüksek 10 yaygın gazetesi içinden seçilen Hürriyet, Milliyet, Sabah, Sözcü ve Yeni Şafak gazetelerinin haber sitelerinde 1 Mart - 31 Aralık 2020 tarihleri arasında yayımlanan köşe yazılarında Covid-19 pandemisinin eğitim alanına etkisinin, pandemi sürecinin yönetilmesinin ve yaşanan dijital dönüşümün ne şekilde değerlendirildiğinin belirlenmesine çalışılmıştır. Bu amaçla köşe yazarlarının uzaktan eğitim sürecine ilişkin 153 köşe yazısı içerik analizi yöntemiyle incelenmiştir. Çalışma kapsamında incelenen köşe yazılarında pandemi sürecinde eğitim-öğretimin işleyişine yönelik olarak Millî Eğitim Bakanlığı'na bağlı okullara üniversitelere oranla daha fazla değinildiği görülmüş, sürecin öğrenciler üzerindeki psikolojik etkileri, Millî Eğitim Bakanlığı ve Yükseköğretim Kurumu'nun süreci nasıl yönettiği, Liselere Geçiş Sınavı ve Yükseköğretim Kurumları Sınavı, özel okulların durumu, teknik altyapı yetersizlikleri ve eğitim-öğretimde firsat eşitsizliğinin ortaya çıkması konularının öne çıktığı belirlenmiş, uzaktan eğitimin örgün eğitimin yerini alamayacağı konusunda fikir birliğinin olduğu sonucuna ulaşılmıştır.

Anahtar Kelimeler: Covid-19, Koronavirüs, Pandemi, Uzaktan Eğitim, İçerik Analizi

Turkish Academic Research Review - Türk Akademik Araştırmalar Dergisi 


\title{
Online Education on the Covid-19 Pandemic Process: A Review on Columns
}

\begin{abstract}
Pandemic was announced on March 11, 2020 as a result of Covid-19 which first appeared in December 2019 and affected the world in a short period. Covid-19 pandemic which became the most important agenda of the world also affected the field of education as well as many other fields in this process. The decisions of transition to online education from a face-to-face education were taken in order to provide social isolation and decrease the virus contagion risk different periods depending on the course of the epidemic of Covid-19 pandemic process. However, it was seen that the applications stated by authorities were discussed from different perspectives and the applications became the agenda of the country in order to eliminate some barriers on transition to online education and to overcome the process with the least damage. In pandemic period, education-instruction process also became the topic of the columns in media outlets and various evaluations were made by columnists related to distance education and various aspects of the topic were discussed.

In this study, we try to find out the effect of Covid-19 pandemic on the field of education, management of pandemic process and the evaluation of digital transformation experienced on the columns published on the news sites of the following newspapers between 1 March - 31 December 2020: Hürriyet, Milliyet, Sabah, Sözcü and Yeni Şafak, which are among the highest general circulation in in Turkey and selected out of 10 prevailing newspapers. 153 columns related to online education process of columnists were analyzed with content analysis method. Within the columns the schools affiliated with Ministry of National Education were dealt with more compared to universities considering education-instruction procedures during pandemic process. Psychological effects of the process on students, management systems of Ministry of National Education and Higher Education Institution, High-school Entrance Exam and Higher Education Foundations Examination, the statuses of private schools, technical infrastructure insufficiencies and emergence of unequal opportunity in education topics were highlighted in the columns. Also, it was concluded that there is a consensus on the topic of online education cannot replace formal education.
\end{abstract}

Keywords: Covid-19, Coronavirus, Pandemic, Online Education, Content Analysis

\section{Structured Abstract}

Pandemic was announced on 11 March 2020 as a result of Covid-19 which occurred on December 2019 in Wuhan state of China for the first time and influenced all the world in a short period of time. Covid-19 pandemic also affected education besides various fields such as health, economy and sports, and caused critical changes in this field. The decisions of transition to online education from a face-to-face education were taken in order to provide social isolation and decrease 
the virus contagion risk in different periods depending on epidemic progress in Turkey where the pandemic process was conducted dynamically.

It was seen that the decisions taken and the applications stated by the authorities, in order to eliminate various barriers on the transition to online education and to be able to overcome the process with the least harm, were discussed considering various perspectives and became the agenda of the country. Education-instruction process was also included in the columns in media outlets in the pandemic period and various evaluations were made related to the topic in these writings.

Columns provide opportunity of monitoring the reflections of the decisions taken on online education and the applications stated considering online education by the authorities. Moreover, it can be said that the columns also carry out one of the most important task of informing citizens and conveying their opinions and thoughts related to the topic into the items of the agenda regarding their criticisms and evaluations.

In this study, it was aimed to determine how the education is interpreted in the pandemic process and the magnitude and type of the dimensions which are highlighted in the columns which are really very effective on public opinion and one of the most important news source of people. Therefore, 153 columns published on the news websites of the following newspapers: Hürriyet, Milliyet, Sabah, Sözcü and Yeni Şafak, which are among the highest general circulation in Turkey between the dates of 1 March - 31 December 2020 were analyzed with content analysis method and the opinions of the columnists related to online education during Covid19 pandemic process were analyzed.

Uncertainty caused increase in the columns on September as a result of the following problems: starting period of schools, technical problems occurred while logging into EBA as a result of intensity, uncertainty in providing education whether face-to-face, online or hybrid. Preschool, primary and secondary schools were dealt with more than universities in the columns. Furthermore, name of Prof. Dr. Ziya Selçuk, Minister of National Education, whose name is mostly cited in the writings and also mostly consulted authority for his comments was included frequently in the following topic contents: EBA TV contents, taking decision of transition to online education from a face-to-face education of the schools during online education process and the outcomes of this decision, measures taken and the measures that must be taken during pandemic process, dates and the course contents included within the scope of the examinations done by Ministry of National Education, taking different decisions between private and public schools, insufficiencies in technical infrastructure, inequality in supplying technical materials for students. It was seen that Ministry of National Education, Higher Education Council and Measurement, Selection and Placement Centre are the most frequently dealt institutions in the columns. The names of these institutions were evaluated by the columnists within the following contexts: process management, decisions taken/that must be taken/are going to be taken, examinations and curriculum, compensatory, EBA TV, starting schools, private schools, opinions of shareholders. Following categories were included in all newspapers in the pandemic period: functioning of educational process, process management of Ministry of National Education, central examinations, private schools and functioning of educational process in the world in the pandemic period. It was observed that the ratio of columns including negative comments in terms of process management are almost equal, the ratio of columns

Turkish Academic Research Review - Türk Akademik Araştırmalar Dergisi 
including positive comments related to Higher Education Council are higher than Ministry of National Education. Issues related to online education process in other countries were not considerably dealt in the columns. The frequency of the following topics included in the columns were almost equal: problems occurred as a result of insufficiencies in technical infrastructure and unequal opportunity in education which are among the most striking topics in online education. Although the subject of online education was taken into consideration with different aspects and perspectives in the pandemic period by columnists, it was concluded that there is a consensus on the topic of online education cannot replace formal education.

\section{Giriş}

Covid-19, ilk kez 2019 yılının aralık ayında Çin'in Vuhan eyaletinde ortaya çıkmıştır (Sağlık Bakanlığı [SB], 2020b). Kısa sürede dünyayı etkisi altına alan ve çeşitli şekillerde isimlendirilen Covid-19 nedeniyle World Health Organization ([WHO] Dünya Sağlı Örgütü) tarafindan 11 Mart 2020'de pandemi ilan edilmiştir (SB, 2020a; WHO, 2020). Pandemi, dünya çapında veya çok geniş bir alanda görülen, uluslararası sınırları aşarak birçok insanı etkileyen salgın olarak tanımlanmaktadır (Porta, 2001, s. 209).

1 Mayıs 2021 itibariyle Türkiye'deki toplam vaka ve toplam vefat sayısının 4.850.000'e 40.500 (SB, 2021b), dünyadaki toplam vaka ve toplam vefat sayısının ise 151.015.000'e 3.174.000 (WHO, 2021a) sayılarına ulaştığ görülmüştür. Aynı tarih itibariyle günlük vaka sayısı değişimi Türkiye'de \%0,67, dünyada $\% 0,59$ iken günlük vefat sayısı değişimi Türkiye' de $\% 0,99$, dünyada $\% 0,47$ olarak seyretmiştir. Bu veriler hem dünya hem de Türkiye açısından Covid-19'un ciddiye alınması ve gerekli tedbirlerin titizlikle uygulanması gerekliliğini ortaya koyması açısından önemlidir.

Türkiye'de ilk vaka Dünya Sağlık Örgütü’nün pandemi ilan ettiği tarihte görülmüştür. Türkiye, aldığı tedbirlerle Covid-19'un ülkeye girişini ancak geciktirebilmiştir. Dünya Sağlık Örgütü, enfeksiyonu önlemek ve bulaşı yavaşlatmak için sunduğu önerilerde özetle hijyen, mesafe ve büyük insan gruplarından uzak durmaya dikkat edilmesi gerektiğini vurgulamaktadır (WHO, 2021b). Türkiye'de konuyla ilgili televizyon, sosyal medya platformları ve web siteleri aracılığıyla Millî Eğitim Bakanlığı (MEB), SB, Yükseköğretim Kurulu (YÖK) veya diğer kurumlar tarafindan vatandaşlar bilgilendirilmeye ve bilinçlendirilmeye çalışılııştır (MEB, 2021f; SB, 2021a; YÖK, 2020g). Yayılımın 
azalmasını sağlamak üzere diğer ülkeler gibi Türkiye'de de farklı zamanlarda riske karşı çeşitli tedbir, kısıtlama ve kararlar alınarak uygulamaya konulmuştur.

Pandemi döneminde her ülke, farklı teknik altyapı gerektiren çeşitli yöntemlerle ülkelerindeki eğitim hizmetlerini kesintiye uğratmadan sürdürmeyi en önemli öncelik haline getirmiştir (Can, 2020). Türkiye, pandemi döneminde Bilim Kurulunun önerilerini dikkate alarak, eğitim alanındaki bilgi, birikim, mevcut altyapı ve yeterliliklerini de göz önünde bulundurarak birtakım kararlar almıştır. Eğitimle alakalı birçok uygulama ortaya konulmasına rağmen bu çalışmanın da konusu olan uzaktan eğitime ilişkin kararların ilki 12 Mart 2020'de alınmıştır. Türkiye'de 16-30 Mart 2020 tarihleri arasında ülke genelindeki tüm okulların tatil edildiği, 23 Mart 2020'den itibaren ilk ve orta dereceli okullardaki uzaktan eğitim sürecine internet üzerinden Eğitim Bilişim Ağı (EBA) ile ve televizyon ekranlarından TRT EBA TV aracılığıyla başlanacağı duyurulmuştur (MEB, 2020a). 25 Mart 2020'de Bilim Kurulunun önerisiyle okulların 30 Nisan 2020'ye kadar tatil edilmesine ve uzaktan eğitimin devam etmesine karar verilmiştir (MEB, 2020c). 30 Mart 2020'de 8 ve 12. sinıflarda okuyan toplam yaklaşık 2.700.000 öğrencinin katılması planlanan pilot çalışmayla EBA Canlı Sınıf uygulamasına başlanmıştır (MEB, 2020d). 29 Nisan 2020'de alınan kararla uzaktan eğitim 31 Mayıs 2020'ye kadar uzatılmıştır (MEB, 2020h). 12 Ağustos 2020'de yapılan açıklamada 20202021 eğitim-öğretim yılının 31Ağustos 2020'de uzaktan eğitimle açılacağ1, 21 Eylül 2020 'de ise Bilim Kurulu tavsiyeleri doğrultusunda aşamalı ve seyreltilmiş olarak yüz yüze eğitime başlanacağı duyurulmuştur (MEB, 2020k). 11 Eylül 2020'de ise okul öncesi ve ilkokul 1. sınıf öğrencileriyle yüz yüze eğitime başlanacağı, öğrencilerin yüz yüze eğitime katılımlarının isteğe bağlı olduğu ve uyum haftasında 1 gün diğer haftalarda ise 2 gün okula gidileceği, ihtiyaç halinde sınıfların gruplara bölünebileceği belirtilmiştir (MEB, 2020m). 2, 3, 4, 8 ve 12. sınıflarda 2. aşama olarak yüz yüze eğitime 12 Ekim 2020'de haftada 2 gün olarak başlanacağı, okul öncesi kurumlarda ise haftada 5 gün eğitim yapılacağı, köy ve benzeri seyrek nüfuslu yerleşimlerde bulunan ilkokul, ortaokul ve imam hatip ortaokullarının bütün sınıflarında il hıfzıssıhha kurulları ve il/ilçe millî eğitim müdürlükleriyle birlikte alınacak kararlar doğrultusunda derslerin tamamının yüz yüze işleneceğini ilan edilmiştir (MEB, 2020n). Yüz yüze eğitimde 3. aşamanın 5 ve 9. sınıflar ile imam hatip ortaokulları haftada 2 gün olarak 2 Kasım 2020 tarihinde başlaması planlanmış ve ayrıca öğrencisini yüz yüze eğitime göndermek istemeyen veliden yazılı onay alınması istenmiştir (MEB, 2020o). Dünya ve Türkiye'deki vaka sayısındaki yükseliş neticesinde öğrenci, öğretmen ve çalışanların etkilenmemesi amacıyla yüz yüze eğitimin sonlandırılması, 20 Kasım 2020'den 4 Ocak 2021'e kadar resmî, özel,

Turkish Academic Research Review - Türk Akademik Araştırmalar Dergisi https://dergipark.org.tr/tr/pub/tarr 
1298 Covid-19 Pandemi Sürecinde Uzaktan Eğitim: Köşe Yazıları Üzerine Bir İnceleme

örgün ve yaygın tüm eğitim-öğretim faaliyetlerinin uzaktan eğitimle yürütülmesi kararı alınmıştır (MEB, 2020p).

MEB tarafindan yapılan diğer bir açıklamada ilkokul, ortaokul ve liselerde ilk dönemin sona ereceği tarih olan 22 Ocak 2021'e kadar uzaktan eğitimin devam edeceği tebliğ edilmiştir (MEB, 2020r). 2020-2021 bahar dönemine ilişkin kararda ise birleştirilmiş sınıf uygulaması yapılan okulların tamamında, köy ve benzeri seyrek nüfuslu yerleşimlerdeki tüm köy ilkokul, ortaokul, bağımsız anaokullarında ve özel eğitim anaokullarında il hıfzıssıhha kurulları ve il/ilçe millî eğitim müdürlükleriyle birlikte alınacak kararlar doğrultusunda 15 Şubat 2021'de haftada 5 gün yüz yüze eğitime geçileceği, 1 Mart 2021'den itibaren tüm resmî ve özel ilkokullar ve bünyelerindeki ana sınıfı ile özel eğitim sınıflarında haftada 2 gün yüz yüze eğitim yapılacağı, 5,6 ve 7 . sınıflarda tüm derslerin uzaktan eğitimle verileceği, tüm resmî ve özel ortaokullar ile imam hatip ortaokullarının 8 . sınıflarında uygulanacak yüz yüze eğitim günlerinin ve eğitim başlangıç/bitiş saatlerinin öğretmenlerle birlikte okul yönetimi tarafindan belirlenmesi (MEB, 2021a), liselerde uzaktan eğitime geçileceği, 12. sınıflarda seyreltilmiş olarak yüz yüze eğitimin haftada en az 16 en fazla ise 24 saat olacak şekilde eğitim kurumu müdürlüklerince belirlenip planlanması gerektiği (MEB, 2021b) ifade edilmiştir. Bütün risk gruplarında yer alan illerdeki ilkokulların tüm sınıflarında ve ayrıca düşük/orta risk gruplarındaki illerdeki 5, 6 ve 7. sınıflarında eğitimin 2 gün yüz yüze ve 3 gün uzaktan eğitimle sağlanmasına, yüksek/çok yüksek risk gruplarında yer alan illerdeki 5, 6 ve 7. sinıflarda yalnızca uzaktan eğitimin uygulanmasına, 8. sınıflarda ise bütün risk gruplarındaki illerde sınıfın bölünmesi gereken durumlarda eğitimin 12 saat diğer durumlarda ise 22 saat olarak yürütülmesine, yüksek/çok yüksek riskli illerdeki ortaöğretim kurumlarının hazırlık, 9, 10 ve 11. sınıflarında uzaktan eğitime geçilmesine, 12. sınıflarda ise yüz yüze eğitimde seyreltilmiş sınıf olarak haftada en az 16 en fazla ise 24 saat olacak şekilde planlanmasına karar verildiği duyurulmuştur (MEB, 2021c). Son olarak 15 Nisan 2021'den itibaren 8 ve 12. sınıflar ile okul öncesi eğitim kurumları dışındaki tüm kademelerde 15 Nisan 2021'den itibaren uzaktan eğitime geçilmiştir (MEB, 2021d). Alınan kararlardan anlaşıldığı üzere sürecin dinamik bir şekilde yönetildiği hem dünya hem de Türkiye'deki vaka sayılarının, buna ek olarak salgın gidişatının alınan kararlarda etkili olduğu, alınan kararların bu değişkenlere bağlı olarak şekillendiği ve Bilim Kurulunun önerilerinin de göz önünde bulundurulduğu görülmüştür.

Uzaktan eğitim kararları başka tartı̧̧maları da beraberinde getirmiştir. Tablet, akıllı telefon ve internet yokluğu veya bunların kısıtlı olması uzaktan eğitime erişimdeki en büyük problemler olarak görülmektedir. Her ne kadar Millî Eğitim 
Bakanı, internet erişimiyle ilgili bazı kısıtların bulunması ve erişimle ilgili en hızlı araç olması nedeniyle televizyonu uzaktan eğitimin merkezi (MEB, 2020b) olarak sunmuş olsa da uzaktan eğitim sürecinin aktif olarak yürütülmesi, öğretmenlerin sınıflarıyla canlı derslere başlaması ve bir evde aynı anda birden fazla derse girmek durumunda olan öğrenci olmasıyla birlikte yeterli sayıda veya nitelikte tablet/akıllı telefon/bilgisayar yokluğu veya olanların derse erişim için gerekli özelliklere sahip olmaması, internetlerinin bulunmaması gibi çözülmesi gereken birtakım problemler ortaya çıkmıştır. Buna ilişkin olarak pandemi sebebiyle aniden denilebilecek şekilde ortaya çıkan bu durumla ilgili MEB EBA mobil destek aracı, EBA destek noktaları, tablet ve internet desteği gibi uygulamalarla öğrencilerin eğitim-öğretim hizmetlerini kullanmaları önündeki engelleri kaldırmaya yönelik projeler ortaya koymuştur. Bunlardan biri olan kırsal kesimdeki erişim gereksinimi olan öğrenciler için oluşturulan Mobil EBA Destek Aracı sayısı 1 Mayıs 2021'de 187'ye ulaşmışır (MEB, 2021g). Evlerinde uzaktan eğitim erişme imkanları bulunmayan öğrencilerin EBA'dan faydalanmaları amaciyla okul ve kurumlarda kurulan EBA destek noktalarının sayısı 2 Eylül 2020'de 1420 iken (MEB, 20201) 1 Mayıs 2021'de 15.272'ye ulaşmış durumdadır (MEB, 2021g). Cihaz ve internet ihtiyacı olanlara destek olmak amaciyla EBA platformlarında kullanılmak üzere 25GB interneti bulunan tabletlerin dağıtımının yapıldığı 12. faza kadar 700.000'ün üzerinde tabletin dağıtımı gerçekleş̧irilmiştir (MEB, 2021e). Öte yandan EBA içeriklerine erişimlerde kullanılmak üzere Türkiye'nin üç büyük GSM operatörünün her ay için 8GB'a kadar ücretiz hizmet sunmasıyla başlayan uzaktan eğitime destek (MEB, 2020e), 1 Mayıs 2021 itibariyle 7 operatöre çıkartılmış ve böylece daha fazla öğrencinin eğitim-öğretim kaynaklarından istifade etmesi önündeki engelin ortadan kaldırılması sağlanmıştır (MEB, 2021h). Fakat ücretsiz internet hizmetinin yalnızca EBA içeriklerine erişimde kullanılması, canlı derslerinse Zoom gibi platformlarda yürütülmesi nedeniyle bu hizmetten faydalanma alanının diğer canlı ders platformlarını da kapsayacak şekilde genişletilmesi gerekliliği ortaya çıkmıştır.

Teknik konuların yanı sıra pandeminin psikolojik etkilerini hafifletmek adına da MEB tarafindan çeşitli projeler uygulamaya konmuştur. Bunlardan birinde sağlık, eğitim ve psikososyal destek gibi konularda her gün konusunun uzmanı biri tarafından öğrencilerin ailelerine yönelik bilgilendirmeler yapılmıştır (MEB, 2020f). Buna ek olarak öğrencilere yönelik koronavirüsle mücadelede psikolojik destek rehberi hazırlanarak yayımlanmıştır (MEB, 2020g). Pandemi sonucu ortaya çıkan dijitalleşmenin hayatı sarması sebebiyle velileri ve öğrencileri konu hakkında bilinçlendirmek, akıldaki soruları yanıtlamak adına “Güvenli İnternet Kullanımı” ve "Siber Zorbalık" konularında 2 kılavuz hazırlanmıştır (MEB, 2020j). Öte yandan

Turkish Academic Research Review - Türk Akademik Araştırmalar Dergisi 
1300 Covid-19 Pandemi Sürecinde Uzaktan Eğitim: Köşe Yazıları Üzerine Bir İnceleme

öğrenci, veli ve öğretmenlerin uzaktan eğitime ait sorularının yanıtlanmasını sağlayan, yapay zekâ teknolojisiyle çalışan EBA Asistan uygulaması geliştirilerek hizmete sunulmuştur (MEB, 2020i).

Yükseköğretim kurumlarında 16 Mart 2021 itibariyle eğitim-öğretime 3 hafta ara verildiği ilan edilmiştir (YÖK, 2020a). 123 üniversitede Uzaktan Öğretim Uygulama ve Araştırma Merkezi bulunduğu, uzaktan eğitim kapasitesine sahip bütün üniversitelerde 23 Mart 2020'de uzaktan öğretim sürecinin başlanacağı belirtilmiştir (YÖK, 2020b). Aynı tarihte 27 lisans ve 47 ön lisans programının dijital ders materyali ile 7 programın lisans tamamlama ders materyallerinin bulunduğu açık ders havuzunun, YÖK Dersleri Platformu (YÖK, 2020c) adı altında açık erişime sunulduğu ifade edilmiştir (YÖK, 2020d). 26 Mart 2020 tarihli basın açıklamasında 2019-2020 Bahar döneminde eğitim-öğretim faaliyetlerinin yalnızca uzaktan eğitim, açık öğretim ve dijital öğretim imkânlarıyla sürdürülmesi kararı verildiği bildirilmiştir (YÖK, 2020e). 2020-2021 eğitim-öğretim dönemine yönelik açıklamada dinamik bir süreç olan salgının bölgesel/yerel seyrine göre kampüste bulunacak öğrencilerin seyreltilmesi ve hareketliliğin azaltılmasına vurgu yapılarak üniversitelerin birbirlerinden farklı uygulamalar yapabilmesine imkân tanınması, üniversitelerde fakülte ve program bazlı dahi kararlar alınarak uygulanabilmesinin mümkün kılınması sağlanmıştır (YÖK, 2020h). Uzaktan eğitim erişimlerine destek olmak üzere sistemde yer alan üniversitelerin sağladığı ders içerikleri ve online eğitimlerde kullanabilecekleri 6GB'lık ücretsiz internet kullanımı öğrencilere sunulmuştur (YÖK, 2020f).

Bilgisayar, tablet, akıllı telefon ve internet gibi yaygın olarak kullanılan teknolojik ürünlerin insan hayatında ne kadar önemli yer tuttuğunun, bu ürünlerin amacına uygun olarak kullanıldığında hayatı kolaylaştıran birer ürüne dönüştüklerinin pandemi döneminde daha iyi anlaşıldığını söylemek yanlış olmaz. Teknolojik ürünler ve gelişmeler, hayatın birçok noktasında farklılaşma meydana getirdiği gibi insanların haber alma kaynaklarında ve şekillerinde de değişikliklere yol açmıştır. Bunda artan iş temposu içerisinde çok hızlı değişkenlik gösteren dünya ve ülke gündeminin takip edilme isteğinin etkili olduğu da söylenebilir.

Gerek yerel gerekse global gündemi takip etmenin çeşitli yolları vardır. Sosyal medya, basılı medya ve internet gazeteleri günümüzün en önemli haber kaynaklarındandır. Basılı medyanın dijital ortama aktarılması şeklinde başlayan internet gazeteciliği günümüzde sosyal medya kavramı ile birleşmiştir. Dahası birçok ulusal gazetenin sosyal medya platformlarında habercilik faaliyeti yürüttükleri söylenebilir (Ünalan, 2021). Son dakika haberleri girebilmenin, 
içeriklere istenilen sayıda resim ekleyebilmenin, içeriklerde ses ve videolara yer verebilmenin, içerikleri güncelleyebilmenin mümkün olması gibi sebepler bilgi sunumunun ve bilgiye erişim hızının oldukça önemli olduğu günümüzde bilişim teknolojileri kullanılarak yapılan gazeteciliği basılı medyadan daha avantajlı konuma geçirmiştir.

Köşe yazarlarının gündemle veya gündem dışı konularda ilgili yazmaları ve hatta bazı köşe yazarlarının yazdıklarının gündem olması, gazete ve okuyucu açısından köşe yazarlarının önemini arttırmaktadır. Ayrıca, gün içinde gündemin hızlı değişmesi gibi birtakım nedenlerle köşe yazarları, köşe yazılarını baskı sonrası güncellemek isteyebilirler. Basılı medyada mümkün olmayan bu işlem yalnızca gazetelerin dijital ortamında gerçekleştirilebilir. Öyle ki gazetenin dijital ortamında bazı köşe yazarlarının gün içerisinde birden fazla farklı köşe yazısına rastlamak mümkündür. $\mathrm{Bu}$ nedenle bir köşe yazarının bütün yazılarına erişmek için basılı medya yerine internet gazetesini kullanmak daha doğru olacaktır.

“Öğrenci ile öğretmenin yüz yüze olmadan çeşitli iletişim araçları kullanılarak belli bir merkezden yapılan eğitim biçimi” (Türk Dil Kurumu, 2021) şeklinde tanımlanan uzaktan eğitim gibi normal zamanlar için sıradan konular, normal olmayan bazı zamanlarda çok önemli hale gelerek gündem olabilir. Uzaktan eğitim, pandemi döneminin eğitimle alakalı en çok tartışılan ve gündem olan konularından biridir. Siyasiler, sağlık bilimciler, eğitim bilimciler, konunun uzmanları ve gazeteciler tarafindan ele alınan bu konu veliler, öğrenciler ve diğer paydaşlar tarafından ilgiyle takip edilmektedir.

Köşe yazıları, yetkililere uzaktan eğitimle ilgili aldıkları kararların ve buna paralel ortaya konulan uygulamaların yansımalarını izleme firsatı sunmaktadır. Ayrıca köşe yazılarının vatandaşları bilgilendirmek, onların eleştiri ve değerlendirmelerine kulak vererek konu hakkındaki duygu ve düşüncelerini gündeme taşımak gibi oldukça önemli bir görevi de yerine getirdikleri söylenebilir. Köşe yazılarında konular genellikle tek bir perspektiften bakılarak değerlendirilmemekte; konular köşe yazarları tarafindan bütün yönleriyle geniş bir bakış açısı ortaya koyacak şekilde etraflıca işlenerek irdelenmektedir. Bu özellikleri sebebiyle bu çalışmada gazetelerin en çok takip edilen unsurlarından olan köşe yazarlarının Covid-19 pandemi sürecinde uzaktan eğitime ilişkin görüşleri içerik analizi yöntemiyle incelenmiştir.

Turkish Academic Research Review - Türk Akademik Araştırmalar Dergisi 


\section{Problem}

Türkiye'de Covid-19 pandemisi nedeniyle 2020 y1lının mart ayında okul öncesi-ilk-orta dereceli okullar ve üniversiteler uzaktan eğitime geçmiştir. Pandeminin seyrine bağlı olarak çeşitli dönemlerde okul öncesi-ilk-orta dereceli okullar ve üniversitelerin bazı bölümlerinde yüz yüze ya da hibrit eğitim uygulanmıştır. Genel olarak eğitim sisteminin ve öğrencilerin bu süreci en az zararla atlatılabilmesine yönelik çeşitli kararlar alınarak uygulamaya geçilmiştir. Bu süreçte bir ülkenin temel taşlarından olan eğitim konusu ve pandemi sürecinde eğitime yönelik politikalar tartışma konusu olmuştur. Pandemi sürecinde eğitim gibi toplumun tüm kesimlerini ilgilendiren, önemi tartışılmaz derecede büyük olan bir konuda halkın fikirleri üzerinde oldukça etkili, en önemli kaynaklardan birisi olan köşe yazılarında eğitim konusunun nasıl yorumlandığı, ne ölçüde ve hangi boyutlarıyla öne çıkarılmış olduğu bir problem olarak karşımıza çıkmaktadır. Bu doğrultuda çalışmanın problemini, köşe yazarlarının pandemi sürecinin eğitime etkisini ne şekilde ele aldıkları, uzaktan eğitime yönelik olarak hangi içerikleri ön plana çıkardıkları, uzaktan eğitim sürecine karşı nasıl bir tutuma sahip oldukları oluşturmaktadır.

\section{Amaç ve Yöntem}

Bilindiği üzere pandemi süreci, tüm dünyada olduğu gibi Türkiye'de de okul öncesi-ilk-orta dereceli okullar ve yükseköğretim kurumlarını büyük ölçüde etkilemiş, uzaktan eğitim ve eğitimde dijital dönüşüm konuları daha sık gündeme gelmeye başlamıştır. Bu çalışmanın amacı, Covid-19 pandemisinde en çok etkilenen alanlardan birisi olan eğitim ve uzaktan eğitim konusunun yaygın gazetelerde yayımlanan köşe yazılarında ne ölçüde ve ne şekilde yer aldığının incelenmesidir.

Çalışmada pandemi döneminde Türk basınında uzaktan eğitim sürecinin ne şekilde değerlendirildiği aşağıdaki sorular doğrultusunda araştırılmıştı;

- Pandemi sürecinde uzaktan eğitim konusuna hangi internet gazetelerinde, ne ölçüde yer verilmiştir?

- Pandemi sürecinde uzaktan eğitim konulu köşe yazılarında hangi içeriklere yer verilmiştir?

- Pandemi sürecinde uzaktan eğitim konulu köşe yazılarında kimlerin görüş ve açıklamalarına yer verilmiştir?

- Uzaktan eğitim sürecinde eşitsizliğe ve teknik altyapı eksikliklerine ne ölçüde değinilmiştir?

- Köşe yazılarında ilgili eğitim kurumlarının süreci yönetmesine yönelik tutum ne yöndedir? 
- Köşe yazılarında diğer ülkelerde eğitim sürecinin yönetilmesiyle ilgili karşılaştırma yapılmış mıdır?

- Köşe yazılarında hangi eğitim kurumlarına daha sık yer verilmiştir?

$\mathrm{Bu}$ çalışma, pandemi nedeniyle eğitim alanında yeni modellerin ve bakış açılarının öne çıktığı, klasik eğitim anlayışının değişmek zorunda kaldığı, iletişim ve bilişim teknolojilerinin daha da fazla önem kazandığı bu süreçte eğitim alanında yaşanan zorlu geçiş sürecinin ve yeni eğitim modellerine ayak uydurma zorunluluğunun, böylesine güncel ve toplumsal bir sorunun köșe yazıları özelinde medya tarafından nasıl yorumlandığının ortaya konulması bakımından önemli bir rol oynamaktadır.

\section{Yöntem}

$\mathrm{Bu}$ çalışmada "kamusal iletişimin belirli boyutlarını belirli amaçlar açısından analiz" (Türkdoğan ve Gökçe, 2015, s. 352) esasına dayanan bir yöntem olan içerik analizi kullanılmıştır. İçerik analizi, nicel verileri öne alan bir yöntem olduğu yönünde eleştirilere maruz kalsa da 1960’lardan sonra nicel ve nitel verilerin birbirini beslediği ve neticede sorgulayıcı çıkarımların yapılmasına olanak sağlayan bir yöntem haline gelmiştir (Yıldırım, 2015, s. 148-149). "İçerik analizi, mevcut metinlerden hareket ederek sosyal gerçeğe (kaynağa, hedefe/okuyucuya ve sosyal ortama) yönelik temel öngörüler/çıkarımlar ya da önermeler elde etmeyi amaçlamaktadır” (Türkdoğan ve Gökçe, 2015, s. 349).

Çalışma, Türkiye'de tirajı en yüksek ilk 10 yaygın gazete içinden seçilen Hürriyet, Milliyet, Sabah, Sözcü ve Yeni Şafak gazetelerinde genel olarak eğitim konusunda yazan köşe yazarlarının yazılarıyla gerçekleştirilmiştir. İlk olarak haber sitelerinden yazarların 1 Mart - 31 Aralık 2020 tarihleri arasındaki 420 köşe yazısı alınmıştır. İlgili köşe yazıları "uzaktan eğitim”, “çevrimiçi eğitim” ve “online eğitim" anahtar sözcükleri kullanılarak taranmış ve çalışma kapsamında 157 köşe yazısı incelenmiştir. Milliyet’te yer alan 4 köşe yazısında “uzaktan eğitim” anahtar sözcüğü geçmesine rağmen konuyla ilgili olmadığı için kapsam dışı bırakılmıştır. Amaç bölümünde yer alan araştırma sorularını yanıtlayabilmek için ilgili köşe yazıları içerik analizine tabi tutulmuştur. Bu doğrultuda öncelikle köşe yazılarının tamamı çözümleme birimi olarak saptanmıştır. Çalışmada neyin kodlanıp kodlanmayacağına yönelik kodlama yönergesi belirlenmiştir. Sonrasında araştırmanın amacını yansıtan ve araştırma sorularını yanıtlamayı sağlayacak ilgili kategoriler belirlenmiş, kodlamalar yapılarak bulguların yorumlanması işlemi gerçekleştirilmiştir.

Turkish Academic Research Review - Türk Akademik Araştırmalar Dergisi https://dergipark.org.tr/tr/pub/tarr 
1304 Covid-19 Pandemi Sürecinde Uzaktan Eğitim: Köşe Yazıları Üzerine Bir İnceleme

Kodlama işlemi iki araştırmacı tarafından gerçekleştirilmiştir. Kodlayıcılar arası uyum, \%90’dır. Güvenirlik testi aşağıdaki formül kullanılarak gerçekleştirilmiştir (Gordon'dan aktaran Yıldırım, 2015, s.145).

Güvenirlik Katsayısı $=2 * C_{1,2} /\left(C_{1}+C_{2}\right)$

$\left(C_{1,2}\right.$, kodlayıcıların birbiriyle uyumlu kodlama sayısı; $C_{1}, 1$. kodlayıcının kodladıklarının sayısı; $C_{2}, 2$. kodlayıcının kodladıklarının sayısıdır.)

Kodlama işlemi sonrasında iki araştırmacı tarafından uyumsuz kodlamalar belirlenmiş ve geçerli kabul edilen kodlama üzerinde uzlaşılmıştır. Köşe yazılarında değinilen içerikler bölümünde (Tablo 6) frekans belirlenmemiş, iki araştırmacının uzlaşarak tespit ettiği 9 içeriğe söz konusu gazetelerin haber sitelerinde değinilip değinilmediği belirlenmiştir.

\section{Bulgular}

\section{Köşe Yazısı Sayıları}

Çalışmada kullanılan uzaktan eğitimle ilgili köşe yazılarının haber sitelerine göre dağılımları Tablo 1'de görülmektedir. Konuyla alakalı 1 Mart - 31 Aralık 2020 tarihleri arasında Hürriyet, Milliyet, Sabah, Sözcü ve Yeni Şafak’ın haber sitelerinde toplam 153 köşe yazısı yayımlanmıştır. En fazla köşe yazısına Milliyet, en az sayıda köşe yazısına ise Sözcü yer vermiştir. Köşe yazılarının \%15,03'ü Hürriyet, \%55,56's1 Milliyet, \%15,69’u Sabah, \%3,92'si Sözcü, \%9,80’i Yeni Şafak gazetelerinin haber sitesinde yer almıştır.

Uzaktan eğitimin konu edildiği köşe yazılarının aylara göre dağılımları Tablo 1'de verilmiştir. Pandemi sürecinde toplamda en fazla köşe yazısı eylül, en az köşe yazısı ise mart ayında yayımlanmıştır. Haber sitelerinde eylül ayında 25, aralıkta 24 , ağustosta 21 , ekimde 17 , nisanda 14, haziranda 12, mayıs, temmuz ve kasımda 11, mart ayında ise 7 köşe yazısına rastlanmıştır. Eylül ayında Milliyet'te 18 köşe yazısı yer almıştır. Okulların açılma süreci olması; yoğunluk nedeniyle EBA'ya girişte teknik sorunların yaşanması; eğitimin yüz yüze, uzaktan ya da hibrit mi yapılacağı konusundaki belirsizlik köşe yazılarının eylül ayında yoğunlaşmasına neden olmuştur. Hürriyet'te haziran, Sabah'ta mart, Sözcü'de nisan, mayıs ve haziran, Yeni Şafak'ta ise mayıs ve kasım aylarında konuya ilişkin köşe yazısı bulunmamaktadır. Milliyet'te ise 10 aylık süreçte tüm aylarda köşe yazısına yer verilmiştir. 
Tablo 1. Köşe Yazılarının Haber Sitelerine ve Aylara Göre Dağılımı

\begin{tabular}{|l|l|l|l|l|l|l|}
\hline Aylar & Hürriyet & Milliyet & Sabah & Sözcü & Yeni Şafak & \\
\hline Mart & 2 & 3 & - & 1 & 1 & 7 \\
\hline Nisan & 2 & 4 & 3 & - & 5 & $\mathbf{1 4}$ \\
\hline Mayıs & 3 & 5 & 3 & - & - & $\mathbf{1 1}$ \\
\hline Haziran & - & 8 & 2 & - & 2 & $\mathbf{1 2}$ \\
\hline Temmuz & 2 & 6 & 1 & 1 & 1 & $\mathbf{1 1}$ \\
\hline Ăgustos & 3 & 12 & 3 & 1 & 2 & $\mathbf{2 1}$ \\
\hline Eylül & 3 & 18 & 3 & - & 1 & $\mathbf{2 5}$ \\
\hline Ekim & 2 & 9 & 4 & 1 & 1 & $\mathbf{1 7}$ \\
\hline Kasım & 3 & 7 & 1 & - & - & $\mathbf{1 1}$ \\
\hline Aralık & 3 & 13 & 4 & 2 & 2 & $\mathbf{2 4}$ \\
\hline & $\mathbf{2 3}$ & $\mathbf{8 5}$ & $\mathbf{2 4}$ & $\mathbf{6}$ & $\mathbf{1 5}$ & $\mathbf{1 5 3}$ \\
\cline { 2 - 6 } & & & & & & \\
\end{tabular}

\section{Okul Türleri}

Okul türlerinin pandemi sürecinde köşe yazılarında yer alma sıklıkları incelenmiş ve bunlara ait veriler Tablo 2'de sunulmuştur. Eğitim ve öğretimi kapsayan genel ifadelerin yer aldığı köşe yazıları hem MEB'e bağlı okullar hem de üniversiteler kategorilerinde incelenerek değerlendirilmiştir. Köşe yazılarına bakıldığında haber sitelerinde okul öncesi-ilk-orta dereceli okulların yer alma sıklığının tüm gazetelerde toplamda üniversitelerin 2 katından daha fazla olduğu görülmüştür. Hürriyet'te yer alan köşe yazıları toplamda değinilen okullara oranlandığında \%76,67'sinin okul öncesi-ilk-orta dereceli okullara, \%23,33'ünün üniversitelere; Milliyet'te \%65,57'sini okul öncesi-ilk-orta dereceli okullara, \%34,43'ünün üniversitelere; Sabah’ta \%96,00'1nın okul öncesi-ilk-orta dereceli okullara, \%4,00’ının üniversitelere; Sözcü’de \%75,00'ının okul öncesi-ilk-orta dereceli okullara, \%25,00'1nın üniversitelere; Yeni Şafak'ta \%56,52'sinin okul öncesi-ilk-orta dereceli okullara, \%43,48'inin üniversitelere ilişkin olduğu saptanmıştır. Üniversite kategorisinin bu oranları kendi içlerinde değerlendirildiğinde Milliyet ve Yeni Şafak'ta diğer gazetelere göre daha fazla yer aldığı görülmüştür. Okul öncesi-ilk-orta dereceli okullara değinilme oranına bakıldığında ise Sabah'ta yer alan köşe yazılarında diğer gazetelere göre bu oranın daha yüksek olduğu tespit edilmiştir. Bu veriler doğrultusunda pandemide eğitimöğretime yönelik yazıların büyük oranda okul öncesi-ilk-orta dereceli okullar bazında ele alındığı, üniversitelere daha az değinildiği söylenebilir.

Turkish Academic Research Review - Türk Akademik Araştırmalar Dergisi 
1306 Covid-19 Pandemi Sürecinde Uzaktan Eğitim: Köşe Yazıları Üzerine Bir İnceleme

Tablo 2. Okul Öncesi-İlk-Orta Dereceli Okullar ve Üniversitelerin Yer Aldığı Köşe Yazısı Sayısı

\begin{tabular}{|l|l|l|l|}
\hline Haber Sitesi & Okul Öncesi-ilk-Orta Dereceli Okullar & Üniversiteler & \multicolumn{1}{l}{} \\
\hline Hürriyet & 23 & 7 & $\mathbf{3 0}$ \\
\hline Milliyet & 80 & 42 & $\mathbf{1 2 2}$ \\
\hline Sabah & 24 & 1 & $\mathbf{2 5}$ \\
\hline Sözcü & 6 & 2 & $\mathbf{8}$ \\
\hline Yeni Şafak & 13 & 10 & $\mathbf{2 3}$ \\
\hline & $\mathbf{1 4 6}$ & $\mathbf{6 2}$ & $\mathbf{2 0 8}$ \\
\hline
\end{tabular}

\section{Adı Geçen Kişiler}

Tablo 3'te görüleceği üzere köşe yazılarında en çok adı geçen kişi, Millî Eğitim Bakanı Prof. Dr. Ziya Selçuk'tur. Milliyet'te 23, Hürriyet'te 9, Sabah'ta 4, Sözcü'de 4, Yeni Şafak’ta 2 olmak üzere toplam 42 köşe yazısında Bakanın adı geçmektedir. Cumhurbaşkanı Recep Tayyip Erdoğan'a ise Milliyet'te 9, Sözcü'de 3, Sabah ve Yeni Şafak'ta 1 olmak üzere toplam 14 yazıda değinilmiştir. Mustafa Kemal Atatürk, Sözcü'de 3 köşe yazısında yer almıştır. YÖK Başkanı Prof. Dr. Mehmet Ali Yekta Saraç'ın adı ise Hürriyet ve Sözcü'de 1, Yeni Şafak’ta 3 köşe yazısında geçmiştir. Eğitimci Enver Yücel ise Yeni Şafak’ta 5 köşe yazısında yer almıştır. Sadece bir yazıda değinilen kişiler, “Diğer” kategorisine kodlanmıştır.

Eğitim konusunun hassas bir içerik olması bu konuda en yetkili isimlerden birisi olan Millî Eğitim Bakanı Prof. Dr. Ziya Selçuk’u bütün köşe yazılarında ön plana çıkarmıştır. Köşe yazılarında Bakan Prof. Dr. Ziya Selçuk’un ismi, EBA TV içerikleri, uzaktan eğitim sürecinde okulların online ya da yüz yüze eğitime geçilmesi kararının alınması ve bu kararın sonuçları, pandemi sürecinde okullarda alınan ve alınması gereken tedbirler, MEB tarafından yapılacak sınavların tarihleri ve sınav kapsamında yer alacak ders içerikleri, özel okul ve devlet okullarında farklı kararların alınması, teknik altyapı eksiklikleri, öğrencilerin teknik materyal temini noktasında eşitsizliği gibi içeriklerde sıkça yer almıştır.

Uzaktan eğitime yönelik köşe yazılarında sıklıkla adı geçen bir diğer isim Cumhurbaşkanı Recep Tayyip Erdoğan olmuştur. Cumhurbaşkanı Recep Tayyip Erdoğan’ın ismi pandemi sürecinde Bakanlar Kurulu ve Bilim Kurulu ile yapmış olduğu toplantılar ve bunların sonucunda eğitimde alınan kararlarla ilgili, MEB'den kadro bekleyen öğretmenler ve işten çıkarılma tehlikesiyle karşı karşıya kalan öğretmenlerin sitemlerinde yer almıştır (Güçlü, 2020b, 2020c, 2020e). Ayrıca Milliyet’teki köşe yazısında eğitimle ilgili süreci yönetenlerin aldığı kararları eleştiren nitelikte “Cumhurbaşkanı Recep Tayyip Erdoğan’ın sık sık vurguladığı gibi, o makamlar keyif makamı değil, hizmet makamı. Birileri onlara bunu hatırlatmalı!..” sözlerine yer vermiştir (Güçlü, 2020s). 
Tablo 3. Yazılarda Adı Geçen Kişilerin Yer Aldığı Köşe Yazısı Sayısı

\begin{tabular}{|c|c|c|c|c|c|c|c|}
\hline Kategori & Kişi Adı & Hürriyet & Milliyet & Sabah & Sözcü & Yeni Şafak & \\
\hline 1 & $\begin{array}{l}\text { Millî Eğitim Bakanı Prof. Dr. Ziya } \\
\text { Selçuk }\end{array}$ & 9 & 23 & 4 & 4 & 2 & 42 \\
\hline 2 & $\begin{array}{l}\text { Cumhurbaşkanı Recep Tayyip } \\
\text { Erdoğan }\end{array}$ & - & 9 & 1 & 3 & 1 & 14 \\
\hline 3 & Enver Yücel (Eğitimci) & - & - & - & - & 5 & 5 \\
\hline 4 & $\begin{array}{l}\text { YÖK Başkanı Prof. Dr. Mehmet Ali } \\
\text { Yekta Saraç }\end{array}$ & 1 & - & - & 1 & 3 & 5 \\
\hline 5 & $\begin{array}{l}\text { Bahçeşehir Koleji İcra Kurulu } \\
\text { Başkanı Hüseyin Yücel }\end{array}$ & - & - & 2 & - & 2 & 4 \\
\hline 6 & Sağlık Bakanı Fahrettin Koca & - & 3 & - & - & 1 & 4 \\
\hline 7 & TÖZOK Başkanı Nurullah Dal & 4 & - & - & - & - & 4 \\
\hline 8 & İELEV Genel Müd. Burak Kılanç & - & - & 3 & - & - & 3 \\
\hline 9 & Mustafa Kemal Atatürk & - & - & - & 3 & - & 3 \\
\hline 10 & Aristoteles & - & 2 & - & - & - & 2 \\
\hline 11 & $\begin{array}{l}\text { Bahçeşehir Koleji Genel Müd. } \\
\text { Özlem Dağ }\end{array}$ & 1 & - & 1 & - & - & 2 \\
\hline 12 & $\begin{array}{l}\text { Bahçeşehir Üniversitesi Rektörü } \\
\text { Şirin Karadeniz }\end{array}$ & - & - & 1 & - & 1 & 2 \\
\hline 13 & $\begin{array}{l}\text { MEB Bakan Yardımcısı Mahmut } \\
\text { Özer }\end{array}$ & 1 & - & 1 & - & - & 2 \\
\hline 14 & $\begin{array}{l}\text { OECD Eğitim Direktörü Andreas } \\
\text { Schleicher }\end{array}$ & - & - & - & - & 2 & 2 \\
\hline 15 & ÖZKURBİR Başkanı Hami Koç & 1 & - & 1 & - & - & 2 \\
\hline 16 & Psikoterapist Fatma Özdemir & - & - & 2 & - & - & 2 \\
\hline 17 & TÖDER Başkanı İbrahim Taşel & 2 & - & - & - & - & 2 \\
\hline \multirow[t]{3}{*}{18} & $\begin{array}{l}\text { Türk Eğitim Sen Genel } \\
\text { BaşkanıTalip Geylan }\end{array}$ & - & 2 & - & - & - & 2 \\
\hline & Diğer (87 kategori) & 35 & 16 & 16 & 15 & 6 & 88 \\
\hline & Toplam (105 kategori) & 54 & 55 & 32 & 26 & 23 & 190 \\
\hline
\end{tabular}

\section{Adı Geçen Kurumlar}

Köşe yazılarında adı geçen kurumlarında listelendiği Tablo 4'e göre en çok bahsi geçen kurumlar sırayla MEB, YÖK, özel okullar ve Ölçme, Seçme, Yerleştirme Merkezi (ÖSYM)'dir. Toplam 108 köşe yazısında MEB, 43 köşe yazısında YÖK, 25 köşe yazısında özel okullar, 22 köşe yazısında ÖSYM'nin adı geçmiştir. MEB, YÖK ve özel okullar tüm haber sitelerinde yer almıştır. ÖSYM ise Sözcü ve Yeni Şafak'ta yer alan köşe yazılarında değinilmeyen kurumlar arasındadır. Sadece bir yazıda değinilen kurumlar, "Diğer" kategorisine kodlanmıştır.

Hürriyet’te en sık değinilen kurumlar sırasıyla MEB, özel okullar, YÖK, SB, ÖSYM, Türkiye Özel Okullar Derneği (TÖZOK), Anadolu liseleri ve imam hatip liseleri; Milliyet'te MEB, YÖK, ÖSYM, SB, özel okullar, Anadolu Üniversitesi, imam hatip liseleri, anadolu liseleri, meslek liseleri ve Yurtkur; 
1308 Covid-19 Pandemi Sürecinde Uzaktan Eğitim: Köşe Yazıları Üzerine Bir İnceleme

Sabah’ta MEB, özel okullar, YÖK ve meslek liseleri; Sözcü'de MEB, özel okullar ve imam hatip liseleri; Yeni Şafak’ta ise MEB, YÖK, Bahçeşehir Üniversitesi, özel okullar, Bahçeşehir Kolejive Sabancı Üniversitesi'dir.

Köşe yazılarında en sık adı geçen kurum MEB olmuştur ve MEB'le ilgili köşe yazılarında yer alan içerikler genel hatlarıyla şu şekildedir; Milliyet'teki 85 köşe yazısının 68'inde MEB ile ilgili içeriğe yer verilmiştir. MEB'in uzaktan eğitim sürecini nasıl yönettiğine, alınan ve alınması gereken tedbirlere, MEB tarafından yapılacak sınav tarihleri ve müfredat ile ilgili konulara, yüz yüze eğitimle telafi yapılabilecek mi sorularına, EBA TV ile ilgili öne çıkan başlıklara, okulların açılması, yüz yüze eğitime geçilmesi ya da uzaktan eğitime devam edilmesi durumunda MEB tarafından ortaya konabilecek senaryolara, veli, öğrenci, öğretmenlerin tüm bu süreçlerle ilgili görüşlerine yer vermiştir. Hürriyet ve Milliyet, köşe yazılarında diğer gazetelere nazaran özel okullara daha fazla yer ayırmıştır. Köşe yazılarında özel okullar konusunda görüşüne başvurulan kişi ve kurumlar vasıtasıyla sıklıkla şu sorular gündeme getirilmiştir: Özel okullarda yüz yüze eğitim yapılması gereken alanlarda telafi eğitim yapılıp yapılamayacağı? Öğrencilerin okullara çağrılması durumunda alınması gereken tedbirler ne olacak? Okula gidilmezse ne olur? Sağlık önemleri yeterli mi? Alınamayan eğitimin, servisin, yemeğin ücreti geri ödenecek mi? (Güçlü, 2020g). Bu soruların beraberinde özel okullarla ilgili özel okulda çalışanların görüşlerine de sıklıkla yer verilmiştir (Güçlü, 2020m).

Hürriyet ise 23 köşe yazısının 16'sında MEB ile ilgili içeriğe yer vermiştir. Hürriyet'teki köşe yazılarında MEB ile ilgili uzaktan eğitim sürecini MEB'in nasıl yöneteceği konusunda MEB uzmanlarının açıklayıcı görüşleri, MEB tarafında yapılacak sınavlarla ilgili alınacak tedbirler, özel okulların ücret iadesi yapıp yapmayacağı ile ilgili soru işaretleri, uzaktan eğitim sürecinde ilkokul 1. sınıf öğrencilerinin okuma yazma öğrenmede güçlük yaşaması, EBA TV ile ilgili bilgiler, uzaktan eğitim sürecini MEB, öğrenci, veli ve öğretmenler tarafindan alınması gereken tedbirleri uzman görüşleri ile desteklemesi gibi konu başlıkları öne çıkarılmıştır. 
Tablo 4. Yazılarda Adı Geçen Kurumların Yer Aldığı Köşe Yazısı Sayısı

\begin{tabular}{|c|c|c|c|c|c|c|c|}
\hline Kategori & Kurum Adı & Hürriyet & Milliyet & Sabah & Sözcü & Yeni Şafak & \\
\hline 1 & MEB & 16 & 68 & 11 & 5 & 8 & 108 \\
\hline 2 & YÖK & 4 & 30 & 2 & 1 & 6 & 43 \\
\hline 3 & Özel Okullar & 9 & 6 & 3 & 3 & 4 & 25 \\
\hline 4 & ÖSYM & 2 & 19 & 1 & - & - & 22 \\
\hline 5 & SB & 3 & 8 & 1 & - & - & 12 \\
\hline 6 & $\begin{array}{l}\text { İmam Hatip Ortaokul ve } \\
\text { Liseleri }\end{array}$ & 1 & 5 & - & 2 & - & 8 \\
\hline 7 & Meslek Liseleri & - & 5 & 2 & - & - & 7 \\
\hline 8 & Bahçeşehir Üniversitesi & - & - & - & - & 6 & 6 \\
\hline 9 & Anadolu Liseleri & 1 & 4 & - & - & - & 5 \\
\hline 10 & Anadolu Üniversitesi & - & 5 & - & - & - & 5 \\
\hline 11 & Bahçeşehir Koleji & - & - & - & - & 3 & 3 \\
\hline 12 & Sabancı Üniversitesi & - & - & - & - & 2 & 2 \\
\hline 13 & TÖZOK & 2 & - & - & - & - & 2 \\
\hline 14 & $\begin{array}{l}\text { Türkiye Bilimsel ve } \\
\text { Teknolojik Araştırma } \\
\text { Kurumu (TÜBİTAK) }\end{array}$ & - & 1 & 1 & - & - & 2 \\
\hline \multirow[t]{3}{*}{15} & Yurtkur & - & 2 & - & - & - & 2 \\
\hline & Diğer (59 kategori) & 17 & 21 & 6 & 4 & 11 & 59 \\
\hline & Toplam (74 kategori) & 55 & 174 & 27 & 15 & 40 & 311 \\
\hline
\end{tabular}

\section{Yorumlarına Yer Verilen Kişi ve Kurumlar}

Yorumlarına yer verilen kişi ve kurumların dağılımlarının sunulduğu Tablo 5'e göre Hürriyet'in haber sitesinde toplamda 35, Milliyet'te 80, Sabah'ta 24, Sözcü'de 5, Yeni Şafak'ta ise 8 kişi ve kurumun yorumları yer almıştır. Hürriyet'te en sık yorumu yer alan kişi Millî Eğitim Bakanı Prof. Dr. Ziya Selçuk, Milliyet’te veliler, Sabah'ta İstanbul Erkek Liseliler Eğitim Vakfı (İELEV) Eğitim Kurumları Genel Müdürü Burak Kılanç, Sözcü'de Bakan Prof. Dr. Ziya Selçuk, Yeni Şafak’ta ise eğitimci Enver Yücel olmuştur.

Tüm köşe yazılarına bakıldığında en sık Millî Eğitim Bakanı Prof. Dr. Ziya Selçuk'un yorumlarına yer verildiği görülmüştür. Milliyet'te 13, Sözcü'de 4, Hürriyet'te ise 3 köşe yazısında Bakan Prof. Dr. Ziya Selçuk'un yorumları yer bulmuştur. Milliyet'te ayrıca kurum olarak MEB'in yorumları, 6 köşe yazısında yer bulmuştur. YÖK ve YÖK Başkanı Prof. Dr. Mehmet Ali Yekta Saraç’ın yorumlarının görülme sıklığı ise MEB'e göre oldukça düşüktür. Milliyet'te 2 köşe yazısında YÖK'ün, Yeni Şafak’ta yer alan 1 köşe yazısında ise YÖK Başkanı Prof. Dr. Mehmet Ali Yekta Saraç'ın yorumuna (Diğer kategorisine kodlanmıştır) rastlanmıştır.

Milliyet'te veli, öğretmen ve öğrenci yorumlarına da toplam 36 köşe yazısında yer verilmiştir. Bu noktada Milliyet’te yer alan köşe yazıları diğerlerinden

Turkish Academic Research Review - Türk Akademik Araştırmalar Dergisi https://dergipark.org.tr/tr/pub/tarr 
1310 Covid-19 Pandemi Sürecinde Uzaktan Eğitim: Köşe Yazıları Üzerine Bir İnceleme

ayrılmaktadır. Sabah’ta ise pandemi sürecinde öğrencilerin psiklolojisi en sık üzerinde durulan konulardan birisi olmuştur. $\mathrm{Bu}$ köşe yazılarında öğrencilerin psikolojisiyle ilgili psikolog ve eğitimcilerden oluşan uzmanların görüşlerine yer verilmiştir.

Tablo 5. Yazılarda Yorumlarına Yer Verilen Kişi ve Kurumların Yer Aldığı Köşe Yazısı Sayısı

\begin{tabular}{|c|c|c|c|c|c|c|c|}
\hline Kategori & Yorumuna Başvurulanlar & Hürriyet & Milliyet & Sabah & Sözcü & Yeni Şafak & \\
\hline 1 & $\begin{array}{l}\text { Millî Eğitim Bakanı Prof. Dr. Ziya } \\
\text { Selçuk }\end{array}$ & 3 & 13 & - & 4 & - & 20 \\
\hline 2 & Veli Görüşleri & - & 18 & - & - & - & 18 \\
\hline 3 & Öğretmen Görüşleri & - & 13 & - & - & - & 13 \\
\hline 4 & $\begin{array}{l}\text { Cumhurbaşkanı Recep Tayyip } \\
\text { Erdoğan }\end{array}$ & 1 & 5 & - & - & - & 6 \\
\hline 5 & MEB & - & 6 & - & - & - & 6 \\
\hline 6 & Öğrenci Görüşleri & - & 5 & - & - & - & 5 \\
\hline 7 & Enver Yücel & - & - & - & - & 4 & 4 \\
\hline 8 & $\begin{array}{l}\text { İELEV Eğitim Kurumları Genel } \\
\text { Müdürü Burak Kılanç }\end{array}$ & - & - & 3 & - & - & 3 \\
\hline 9 & $\begin{array}{l}\text { Bahçeşehir Koleji Genel Müdürü } \\
\text { Özlem Dağ }\end{array}$ & 1 & - & 1 & - & - & 2 \\
\hline 10 & $\begin{array}{l}\text { OECD Eğitim Direktörü Andreas } \\
\text { Schleicher }\end{array}$ & - & - & - & - & 2 & 2 \\
\hline 11 & $\begin{array}{l}\text { Özel Eğitim Kurumları TÖZOK } \\
\text { Başkanı Nurullah Dal }\end{array}$ & 2 & - & - & - & - & 2 \\
\hline 12 & Psikoterapist Dr. Fatma Özdemir & - & - & 2 & - & - & 2 \\
\hline 13 & $\begin{array}{l}\text { Türk Eğitim-Sen Başkanı Talip } \\
\text { Geylan }\end{array}$ & - & 2 & - & - & - & 2 \\
\hline 14 & YÖK & - & 2 & - & - & - & 2 \\
\hline & Diğer (65 kategori) & 28 & 16 & 18 & 1 & 2 & 65 \\
\hline & Toplam (79 kategori) & 35 & 80 & 24 & 5 & 8 & 152 \\
\hline
\end{tabular}

\section{Kategoriler}

Eğitim sürecine ilişkin köşe yazılarında tespit edilen 9 adet genel kategorinin bilgileri Tablo 6'da görülmektedir. Pandemi döneminde eğitim sürecinin işleyişi, MEB’in süreç yönetimi, Liselere Geçiş Sınavı (LGS) - Yükseköğretim Kurumları Sınavı (YKS) gibi merkezi sınavlar, özel okullar ve dünyada pandemi döneminde eğitim sürecinin işleyişi kategorilerine tüm gazetelerin köşe yazılarında yer verildiği görülmüştür. Koronavirüsün psikolojik etkileri içeriği Sözcü’de, YÖK'ün/Üniversitelerin süreç yönetimi içeriği ise Sabah'ta yer almamıştır. Açıköğretim Fakültesi (AÖF) sınavları ve yüz yüze eğitimin ertelenmesinin turizme etkisi konularına ise sadece Milliyet’te değinilmiştir.

Koronavirüsün psikolojik etkileri, özellikle Sabah’ta yer alan köşe yazılarında öne çıkan bir içeriktir. Pandemi sürecinin çocukların psikolojisi üzerinde oluşturabileceği olumsuz etkilerin ele alındığı bu köşe yazılarında uzmanların 
görüşlerine başvurularak sürecin en az hasarla atlatılabilmesi için neler yapılabileceğiyle ilgili bilgiler verilmiştir (Gürsoy, 2020a, 2020c). Yeni Şafak’ta sürecin gençlerin psikolojileri üzerindeki olumsuz etkilerine, bu olumsuz etkilerin YKS sınavına girecek adayların performanslarını düşürebileceğine ve bu nedenle gençler için kolaylaştırıcı adımlar atılmasının olumlu olacağı hususlarına değinilmiştir (Polat, 2020b). Hürriyet'te uzaktan eğitim dolayısıyla çocukların uzun süre ekran karşısında kalmalarının etkileri ve çocuklarda ortaya çıkan kaygı bozukluğu değerlendirilmiş ve konuyla ilgili uzman görüşlerine başvurulmuştur (Çakmakçı, 2020h, 2020i). Uzaktan eğitimin sebep olduğu ekran bağımlılı̆̆ı, ders saatlerinin uzunluğu, sınav baskısı ve psikolojik sonuçları Milliyet'te de yer bulmuştur (Güçlü, 2020v, 2020z).

Pandemi döneminde eğitim sürecinin işleyişi içeriği uzaktan eğitimin avantaj ve dezavantajları, uzaktan eğitimin uzatılması, okulların açılması, verimlilik, öğretmenlerin ve velilerin süreç yönetimi, sınavlar, eğitimde dijital dönüşüm gibi birçok temayı içermektedir. Eğitimin işleyişine yönelik sadece durum tespiti yapan ya da işleyişin nasıl olacağına ilişkin bilgi veren köşe yazılarının yanında çözüm önerisi getiren ve eleştiri içeren yazılar da mevcuttur.

Köşe yazılarında tüm haber sitelerinde ilgi odağı olan konulardan birisi de YKS ve LGS gibi merkezi sınavlardır. Sabah’ta uzaktan eğitimin yüz yüze eğitim kadar verimli olmamasının sınava girecek öğrencilerin kaygılarını arttırdığının ve gerekli önlemlerin alınması koşuluyla LGS'nin ertelenmemesinin hazırlık sürecindeki öğrenciler açısından daha olumlu olduğunun üzerinde durulmuş, MEB'in LGS'ye yönelik aldığ1 tedbirlerden ve öğrencilerin bu süreçte neler yapabileceklerinden bahsedilmiştir (Gürsoy, 2020d, 2020e). YKS konusunda ise Ortaöğretim Başarı Puanı'nın (OBP) etkisine değinilerek özellikle pandemi sürecinde bazı okulların öğrencilerine şişirilmiş notlar vermelerinin haksızlığa neden olduğunun ve OBP'nin etkisinin azaltılması gerekliliği üzerinde durulmuştur (Gürsoy, 2020g). Sözcü'de ise konuya LGS ve YKS'de öğrencilerin bütün müfredattan sorumlu olmaları ve okullarda açılan sınav hazırlık kurslarına sokağa çıkma yasağı nedeniyle gidememeleri açısından yaklaşılmıştır. Bazı kolejlerin öğrencilere fazladan not vererek OBP'lerinin yüksek olmalarını sağlamalarının oluşturduğu haksızlığın görmezden gelindiğine yönelik eleştiride bulunulmuştur (Uçar, 2020b). LGS ve YKS'nin ertelenip ertelenmeyeceği Yeni Şafak'ta ele alınan konulardan birisidir. LGS'de öğrencilerin okula gitmemelerinin sınava daha iyi odaklanabilecek olmalarını sağladığı için sınavda herkesin eşit olduğu ve pandemi sürecinin aslında avantaj sağladığına değinilmiştir (Polat, 2020c). Başka bir köşe yazısında ise pandeminin ve sınavların yarattığı baskının öğrenciler üzerindeki

Turkish Academic Research Review - Türk Akademik Araştırmalar Dergisi 
olumsuz etkisine yer verilmiş, MEB'in LGS ve YKS'ye girecek öğrencileri bütün müfredattan sorumlu tutması eleştirilmiştir. 2020 yılında sadece mart, nisan ve mayıs aylarında uzaktan eğitim uygulanmasına karşın yapılan merkezi sınavlarda öğrencilerin 2. dönem konularından muaf tutulmaları, 2021 yılında ise hiç okula gidilmemesine rağmen tüm konulardan sorumlu olmalarının adaletsizliğe neden olacağı üzerinde durulmuştur. YKS konusunda ise 2021 yılında adaletsizlik oluşturan OBP katkısının olmaması ve özel yetenek bölümlerinin sınav puanının sonradan kabul edilmesi önerisi sunulmuştur (Polat, 2020i).

Hürriyet'te LGS ve YKS'de uzaktan eğitim sürecinde işlenen konuların sınava dahil edilip edilmemesi ve sınavların ertelenmesi durumunun öğrencileri strese maruz bıraktığının üzerinde durulmuştur (Çakmakçı, 2020a). MEB'in yayımladığı LGS Başvuru Kılavuzu hakkında bilgi verilerek 2020 LGS'de sadece 1. dönem müfredatından sorumlu olmalarının öğrencilere sağladığı kolaylığa değinilmiştir (Çakmakçı, 2020b). Ayrıca LGS ve YKS'nin nasıl gerçekleştirileceğine ve alınan önlemlere ilişkin bilgi verme niteliğinde 1 köşe yazsına da rastlanmıştır (Çakmakçı, 2020d). Pandemi sürecinde öğrencilerin YKS'ye tam hazırlanamama endişesi de üzerinde durulan konulardan bir diğeridir (Çakmakçı, 2020f).

LGS ve YKS gibi merkezi sınavlar Milliyet'te yer alan köşe yazılarında en sık yer alan içeriklerden birisidir. Milliyet'te pandemi koşullarında LGS ve YKS için gereken önlemlerin alınıp alınmadığına ve sınav sürecine yönelik sorular sorulmuştur (Güçlü, 2020d, 2020e, 2020f). Milli Savunma Üniversitesi ve LGS sınavlarında sosyal mesafe kurallarına uyulmaması eleştirilerek aynı sorunun YKS'de yaşanmaması için bir şeyler yapılması gerektiği belirtilmiş ancak YKS'ye yönelik resmî açıklamaların sadece sınav güvenliğiyle ilgili olması eleştirilmiştir (Güçlü, 2020h). MEB ve YÖK'ün pandemi sürecinde okulların açılması ya da açılmaması noktasında yeterli inisiyatifi alamamaları bunun da LGS ve YKS gibi sınavlar için yüz yüze eğitim alan ve almayan öğrenciler arasında adaletsizliğe sebebiyet vermesi de Milliyet'te LGS ve YKS ile ilgili değinilen konular arasındadır (Güçlü, 2020t, 2020u). Ayrıca 2021 LGS ve YKS'de öğrencilerin tüm müfredattan sorumlu tutulması Milliyet'te de eleştirilen noktalardan birisi olmuştur (Güçlü, 2020y).

Pandemi sürecinde özel okulların durumu, tüm gazetelerde ele alınmıştır. Özel okulların ücret iadesine yönelik tartışmalar, bu süreçte öne çıkmıştır. Sabah’ta köşe yazılarına bakıldığında özel okulların pandemi sürecinde nasıl bir yol izlediğine ve uzaktan eğitime yönelik planlarına değinildiği görülmüştür (Gürsoy, 
2020b). Özel okulların ücret iadesi konusunda da devletin ekonomik tedbirler kapsamında eğitimde Katma Değer Vergisi (KDV) oranlarında indirime gitmesinin ve bunun üzerine bazı özel okulların KDV iadesi yapmasının üzerinde durulmuş, Senin Kariyerin Danışmanlık Kurucusu ve Yeni Asır Gazetesi Ekonomi Yazarı Gonca Elibol'un özel okulların bu süreçte yemek ve servis ücretlerini geri ödemesi gerektiğine yönelik yorumlarına yer verilmiştir (Gürsoy, 2020f). Sözcü'de de verilen teşvikler nedeniyle sayısı fazlaca artan kolejlerin pandemi süreci devam ettiği taktirde iflas edecek olması konu edilmiştir (Uçar, 2020a). Yeni Şafak'ta ise bazı özel okulların hızlı ve etkin bir biçimde uzaktan eğitime başlamaları ve çeşitli uygulamaları konu edilmiştir (Polat, 2020a, 2020f).

Hürriyet'te Özel Öğretim Kurumları Platformu'nun Bakanlık yetkilileriyle online toplantı isteklerine ve telafi eğitimi yapılması durumunda ücret iadesi yapılmayacağına yönelik yorumlara yer verilmiştir (Çakmakçı, 2020c). Özel okul ücretlerinin iadesiyle ilgili bir diğer yazıda da Özel Öğretim Kurumları Dernekleri Platformu'nun servis ve yemek ücretlerinin iadesinin bir sonraki yıla mahsup edilmesi gerektiğine, bazı özel okulların yaşadıkları zorluklar nedeniyle öğretmenleri işten çıkarmak zorunda kaldıklarına ve bu nedenle velilerin ücret iadesi talepleri konusunda bu kurumların ayakta kalabilmesi ve öğretmenlerin desteklenebilmesi için daha hassas davranmalarını beklediklerine yönelik açıklamalarına yer verilmiştir (Çakmakçı, 2020d). Özel okullar içeriği, bu okulların pandemi nedeniyle yaşadıkları zorluklar, yüz yüze eğitim olmadığı için velilerin çocuklarını devlet okuluna geçirmesi ve bu kurumlarda çalışan öğretmenlerin işsiz kalması açısından ele alınmıştır (Çakmakçı, 2020g).

Milliye'te kolejlerin pandemi sürecinde hangi önlemleri aldıkları, ücret iadesi yapılıp yapılmayacağı sorulan sorular arasında yer almaktadır (Güçlü, 2020d). Devletin verdiği teşviklerin yeterli olup olmadığına yönelik sektörden temsilcilerle görüşülmüş, teşvik ve yardımdan faydalandırılmadıklarına, özellikle Okul Öncesi Özel Eğitim Kurumları'nın açıklanan destek paketlerinde fazla yer almadıklarına ve bu şekilde birikmiş borç yüküyle ayakta kalamayacaklarına yönelik yorumlarına yer verilmiştir (Güçlü, 2020a). Kolejlerin devletten kısa çalışma ödeneği almalarına rağmen ücret iadesi yapmamaları konusunda velilerin tepkilerine değinilmiş, okul sahipleri bu noktada eleştirilmiştir (Güçlü, 2020i). Başka bir yazıda da devletin bu konudaki sorumlulukları ön plana alınarak okul sahipleri ve velileri rahatlatacak vergi indirimlerinin söz konusu olup olmadığına ve eğitim sektörüne de teşvik uygulamaları gelmesi gerektiğine değinilmiştir (Güçlü, 2020k, 20201). Özel okulların ücret iadesi yapacaklarına yönelik açıklamaları, velilerin çocuklarını devlet okuluna almadan önce yapılması durumunda daha az kayıp yaşayabilmiş olacakları

Turkish Academic Research Review - Türk Akademik Araştırmalar Dergisi 
1314 Covid-19 Pandemi Sürecinde Uzaktan Eğitim: Köşe Yazıları Üzerine Bir İnceleme

noktasında eleştirilmiş (Güçlü, 2020p), özel okulların velilerin vergisiyle birlikte çoktan ödedikleri ücretleri geri alamayacakları ve bunun özel okulların kayıt oranlarını düşüreceği konusu ele alınmış, MEB ve YÖK'ün bu konuda daha aktif rol alması gerekliliğinin üzerinde durulmuştur (Güçlü, 2020r).

Milliyet'te diğer gazetelerden farklı olarak AÖF sınavları ve yüz yüze eğitimin ertelenerek turizm sektörüne hareketlilik getirilmesi (Güçlü, 2020n) gibi içerikler de yer almıştır. AÖF sınavlarında yeterli güvenliğin sağlanıp sağlanamayacağı, teknik altyapının yeterliliği gibi sorunlara değinilmiş (Güçlü, 2020b), Anadolu Üniversitesi'nin AÖF'de yaz okulunu kaldırarak bunun yerine 3 ders sınavı getirmesinin öğrencilerin tepkisine neden olması ele alınmıştır (Güçlü, 2020j). Yine Anadolu Üniversitesi AÖF’nin, örgün eğitim kurumları uzaktan eğitime geçerken yüz yüze sınav yapması eleştirilen noktalardan birisi olmuştur (Güçlü, 2020o).

Tablo 6. Tespit Edilen Kategorilerin Haber Sitelerindeki Köşe Yazılarında Değinilme Durumları

\begin{tabular}{|l|l|c|c|c|c|c|}
\hline Kategori & İçerik (Genel Kategoriler) & Hürriyet & Milliyet & Sabah & Sözcü & Yeni Şafak \\
\hline 1 & Koronavirüsün psikolojik etkileri & $\checkmark$ & $\checkmark$ & $\checkmark$ & × & $\checkmark$ \\
\hline 2 & $\begin{array}{l}\text { Pandemi döneminde eğitim sürecinin } \\
\text { işleyişi }\end{array}$ & $\checkmark$ & $\checkmark$ & $\checkmark$ & $\checkmark$ & $\checkmark$ \\
\hline 3 & MEB'in süreç yönetimi & $\checkmark$ & $\checkmark$ & $\checkmark$ & $\checkmark$ & $\checkmark$ \\
\hline 4 & LGS-YKS & $\checkmark$ & $\checkmark$ & $\checkmark$ & $\checkmark$ & $\checkmark$ \\
\hline 5 & Özel okullar & $\checkmark$ & $\checkmark$ & $\checkmark$ & $\checkmark$ & $\checkmark$ \\
\hline 6 & YÖK'ün/Üniversitelerin süreç yönetimi & $\checkmark$ & $\checkmark$ & $\mathbf{x}$ & $\checkmark$ & $\checkmark$ \\
\hline 7 & $\begin{array}{l}\text { Dünyada pandemi döneminde eğitim } \\
\text { sürecinin işleyişi }\end{array}$ & $\checkmark$ & $\checkmark$ & $\checkmark$ & $\checkmark$ & $\checkmark$ \\
\hline 8 & AÖF sinavları & $\mathbf{x}$ & $\checkmark$ & $\mathbf{x}$ & $\mathbf{x}$ & $\mathbf{x}$ \\
\hline 9 & $\begin{array}{l}\text { Yüz yüze eğitimin ertelenmesinin turizme } \\
\text { etkisi }\end{array}$ & $\mathbf{x}$ & $\checkmark$ & $\mathbf{x}$ & $\mathbf{x}$ & $\mathbf{x}$ \\
\hline
\end{tabular}

\section{İlgili Kurumların Süreç Yönetimi}

Köşe yazılarının ilgili kurumların süreci yönetmesine yönelik tutumunun ne yönde olduğunu belirlemek amacıyla MEB ve okul öncesi-ilk-orta dereceli okullar ile YÖK ve üniversiteler için ayrı ayrı kodlama yapılmış ve elde edilen veriler Tablo 7'de sunulmuştur. Bu doğrultuda sadece MEB'in ve YÖK'ün süreç yönetimine ilişkin köşe yazıları değerlendirmeye alınmıştır. Verilere bakıldığında MEB'e yönelik olumlu yazıların oranının toplamda \%12,61; olumsuz yazıların oranının $\% 53,15$; nötr tondaki yazıların oranının $\% 34,23$ olduğu görülmüştür. Toplamda YÖK'e yönelik olumlu yazıların oranı \%16,33; olumsuz yazıların oranı $\% 53,06$; nötr tondaki yazıların oranı ise $\% 30,61$ 'dir. Genel toplamda oranlara bakıldığında daha fazla sayıda köşe yazısına konu olan MEB ve YÖK'e yönelik 
olumsuz yazıların oranının neredeyse eşit olduğu görülmektedir. YÖK'e ilişkin olumlu yazıların oranı MEB'e göre daha yüksektir.

Kurumların süreç yönetimine yönelik tutumlarının haber siteleri bazında incelenmesi neticesinde Hürriyet'te MEB ve YÖK'ün süreç yönetimine yönelik olumsuz tutuma rastlanmamıştır; MEB'e yönelik 2 yazıda olumlu, 14 yazıda nötr tutum söz konusuyken YÖK'e yönelik 2 adet köşe yazısı nötr durumdadır. Milliyet'te ise MEB'e ilişkin 4 olumlu, 47 olumsuz ve 20 nötr tutum içeren köşe yazısı belirlenmiştir. YÖK'le ilgili ise 3 olumlu, 23 olumsuz, 12 köşe yazısı ise nötrdür. Sabah'ta MEB'le ilgili 7 adet olumlu, 1 adet nötr köşe yazısı yer alırken, YÖK'le ilgili herhangi bir tutum içeren yazıya rastlanmamıştır. Sözcü'de 2 kurumun da süreç yönetimine yönelik olumlu veya nötr yazıya rastlanmamış; MEB'e yönelik 6, YÖK'e ilişkin ise 1 yazıda olumsuz bir tutum gözlenmiştir.

Yeni Şafak'ta MEB'e yönelik olumsuz yazıların oranı, olumlu ve nötr yazılara göre yüksektir. 1 yazı olumlu, 3 yazı nötr yöndeyken, toplam 6 yazı olumsuz tondadır. YÖK'e yönelik olumsuz yazıların oranı MEB'e yönelik olumsuz yazılara göre düşüktür. Sadece 2 yazı olumsuzken, 5 yazı olumlu, 1 yazı ise nötr tutum içermektedir. Olumsuz kodlanan 2 yazı YÖK'le alakalı olmayıp uzaktan eğitimle ilgili eksiklikleri olan üniversitelerle ilişkilidir (Polat, 2020a, 2020c). YÖK'ün süreç yönetimini en başarılı bulan köşe yazıları Yeni Şafak'ta yer almıştır. YÖK'ün süreci proaktif bir şekilde yürüttüğüne yönelik yorumlara yer verilmiştir (Polat, 2020d).

Tablo 7. İlgili Kurumlarının Süreci Yönetmelerine Yönelik Tutumlarına Göre Köşe Yazısı Sayısı

\begin{tabular}{|l|l|l|l|l|l|l|}
\hline \multirow{2}{*}{ Haber Sitesi } & \multicolumn{2}{l}{ MEB ve Okul Öncesi-Ilk-Orta Dereceli Okullar } & \multicolumn{2}{l|}{ YÖK ve Üniversiteler } \\
\cline { 2 - 7 } & Olumlu & Olumsuz & Nötr & Olumlu & Olumsuz & Nötr \\
\hline Hürriyet & 2 & - & 14 & - & - & 2 \\
\hline Milliyet & 4 & 47 & 20 & 3 & 23 & 12 \\
\hline Sabah & 7 & - & 1 & - & - & - \\
\hline Sözcü & - & 6 & - & - & 1 & - \\
\hline Yeni Şafak & 1 & 6 & 3 & 5 & 2 & 1 \\
\hline & $\mathbf{1 4}$ & $\mathbf{5 9}$ & $\mathbf{3 8}$ & $\mathbf{8}$ & $\mathbf{2 6}$ & $\mathbf{1 5}$ \\
\hline
\end{tabular}

\section{Diğer Ülkelere Değinme}

Köşe yazılarında uzaktan eğitim sürecinde diğer ülkelerde ne gibi uygulamalar gerçekleştirildiğine yönelik bilgilere yer verilip verilmediğini ortaya koymak adına Tablo 8 oluşturulmuştur. Hürriyet ve Sözcü'de 1, Sabah'ta 2, Milliyet'te 5, Yeni Şafak'ta 7 olmak üzere toplam 16 köşe yazısında bu bilgilere yer verildiği görülmüsştür. Diğer ülkelerde pandemi sürecinde eğitime en sık değinilen haber sitesi Yeni Şafak, en az değinilen ise Hürriyet ve Sözcü’dür. Yeni Şafak’ta yer

Turkish Academic Research Review - Türk Akademik Araştırmalar Dergisi 
1316 Covid-19 Pandemi Sürecinde Uzaktan Eğitim: Köşe Yazıları Üzerine Bir İnceleme

alan köşe yazılarında çeşitli ülkelerde okulların açılmış olmasına rağmen Türkiye'de okulların açılıp açılmaması konusundaki belirsizlik (Polat, 2020g) ve pandeminin boyutunun artması nedeniyle ülkelerin uzaktan eğitime geçmesi (Polat, 2020i) gibi yorumlara yer verilmiştir.

Tablo 8. Pandemi Sürecinde Yurtdışında Eğitim Alanında Yapılanlara Değinilen Köşe Yazısı Sayısı

\begin{tabular}{|l|l|}
\hline Haber Sitesi & Köşe Yazısı Sayısı \\
\hline Hürriyet & 1 \\
\hline Milliyet & 5 \\
\hline Sabah & 2 \\
\hline Sözcü & 1 \\
\hline Yeni Şafak & 7 \\
\hline & $\mathbf{1 6}$ \\
\cline { 2 - 2 } &
\end{tabular}

\section{Teknik Altyapı Eksikliği ve Eğitimde Fırsat Eşitsizliği}

Uzaktan eğitimde en dikkat çeken konular arasında yer alan teknik altyapı eksikliğinden kaynaklı sorunlar ve eğitimde firsat eşitsizliği oluşmasının yazılarda değinilme sıklıkları belirlenerek Tablo 9'da gösterilmiştir. Köşe yazılarında bu konulara değinilme sıklığına bakıldığında tüm gazetelerde toplamda 24 yazıda teknik altyapı eksikliğine, 27 yazıda ise eğitimde firsat eşitsizliğine değinildiği belirlenmiştir. Hürriyette yer alan toplam 23 yazının \%13,04'ünde teknik altyapı eksikliğine, \%8,70'inde ise eğitimde firsat eşitsizliğine yer verilmiştir. Milliyet’te bu oran teknik altyap1 eksikliği konusunda \%16,47, eğitimde firsat eşitsizliği konusunda ise \%20,00'dır. Sabah'ta teknik altyapı eksikliğine toplam 24 köşe yazısının \%4,17'sinde, eğitimde firsat eşitsizliğine $\% 8,33$ 'ünde değinilmiştir. Sözcü'de yer alan 6 köşe yazısının \%16,67'sinde, Yeni Şafak'ta ise 15 köşe yazısının \%33,33’ünde hem teknik alt yapı eksikliği hem de eğitimde fırsat eşitsizliği konularına değinilmiştir.

$\mathrm{Bu}$ ve benzeri sorunlara en sık değinmiş olan köşe yazarlarından Abbas Güçlü (2020c) köşesinde öğretmenlerin de öğrencilerin interneti olmadığı, EBA internet paketlerinin derslere katılmak için kullanılamadığı yönündeki tespit ve önerilerine yer vermiştir.

Tablo 9. Teknik Altyapı Eksikliği ve Eğitimde Fırsat Eşitsizliğine Değinilen Köşe Yazısı Sayısı

\begin{tabular}{|l|l|l|}
\hline Haber Sitesi & Teknik Altyapı Eksikliği & Eğitimde Fırsat Eşitsizliği \\
\hline Hürriyet & 3 & 2 \\
\hline Milliyet & 14 & 17 \\
\hline Sabah & 1 & 2 \\
\hline Sözcü & 1 & 1 \\
\hline Yeni Şafak & 5 & 5 \\
\hline & $\mathbf{2 4}$ & $\mathbf{2 7}$ \\
\cline { 2 - 4 } & &
\end{tabular}




\section{Tartışma ve Sonuç}

Devlet Planlama Teşkilatı'nın Bilgi Toplumu Stratejisi'nde eğitim sürecinin temel araçlarından biri olan bilgi ve iletişim teknolojilerini öğrenci, öğretmen ve eğiticilerin etkin kullanımının sağlanmasının belirtildiği görülmektedir (Devlet Planlama Teşkilatı, 2006). Bu anlamda Türkiye'deki eğitim paydaşlarının teknolojiyi kullanmaları hedefi uzun yıllar önce ortaya konulmuş, eğitimde dijitalleşme ve dijital kaynaklar kullanımının başlangıcı çok önceden verilmiştir. Tüm dünyada pandemi koşullarına uyum sağlamanın gereği olarak eğitim alanında da yeniden yapılandırma ihtiyacı ortaya çıkmış, dijital teknolojilerin ulaşılabilirliği ve kullanımı, sağlıklı bir eğitim-öğretim ortamı oluşturulmasında temel ihtiyaçlardan birisine dönüşmüştür. Önümüzdeki günlerde salgın koşullarının değişme ihtimali olsa da pandemi süreci, eğitim-öğretimdeki dijital dönüşüme ve eğitimde yeni modellere hazır olunması gerekliliğini göstermiştir.

Dünya çapında toplumsal bir sorun olarak karşımıza çıkan eğitimöğretimin aksamaması gerekliliği, sağlıklı bir şekilde koşullara uyum sağlayarak sürdürülebilmesi ve dolayısıyla Covid-19 pandemisiyle hayatımızda daha sık duymaya başladığımız uzaktan eğitim süreci önem kazanmıştır. Bu çalışmada 11 Mart 2020 tarihinde küresel salgına dönüştüğü ilan edilen Covid-19 nedeniyle Türkiye'de 23 Mart 2020 itibariyle uygulanmaya başlanan uzaktan eğitimin toplumsal konuların gündeme getirilerek yorumlandığı köşe yazılarına ne ölçüde ve ne şekilde yansıdığı incelenmiş ve elde edilen bulgular ışığında birtakım tespitler gün ışığına çıkarılmıştır.

Köşe yazılarının içerik analizine tabi tutulması doğrultusunda elde edilen veriler neticesinde uzaktan eğitim konusunun çalışma kapsamında incelenen bütün haber sitelerinde farklı oranlarda ve boyutlarda ele alındığını söylemek mümkündür. Milliyet gazetesi köşe yazarı Abbas Güçlü, diğer yazarlara oranla daha sık köşe yazısı yayımlaması neticesinde diğer haber sitelerine oranla çok daha fazla sayıda yazısında uzaktan eğitim konusunu gündeme getirmiştir. Benzer şekilde içerik çeşitliliği de Milliyet'te daha yoğundur. Bilgi veren, durum tespitinde bulunan, eleştiri niteliğinde olan ve çözüm önerisi sunan çok sayıda köşe yazısı mevcuttur. Turgay Polat'ın Yeni Şafak'ta yer alan yazılarında da bilgi verme ve mevcut durumu açıklamanın yanında uzaktan eğitimle ilgili kişi ve kurumların süreci yönetmesine yönelik eleştiriler getirilerek mevcut problemlerin çözümüne yönelik atılması gereken adımlar hakkında öneriler ortaya konulmuştur. Hürriyet'te yer alan köşe yazıları ise daha çok EBA'nın işleyişi, LGS ve YKS sınavları için yapılan hazırlıklar gibi konularda bilgi verme niteliğindedir. Sabah’ta ise uzaktan eğitim süreci,

Turkish Academic Research Review - Türk Akademik Araştırmalar Dergisi 
1318 Covid-19 Pandemi Sürecinde Uzaktan Eğitim: Köşe Yazıları Üzerine Bir İnceleme

öğrencilerin psikolojisi üzerindeki etkileri açısından ele alınmış ve uzmanların görüşlerinden faydalanılmıştır. Sözcü'de yer alan yazılar ise ağırlıklı olarak eleştiri niteliğindedir.

Pandemi döneminde MEB ve YÖK gibi kurumların süreç yönetiminin köşe yazılarında nasıl değerlendirildiğine bakıldığında Hürriyet ve Sabah'ta yer alan yazıların tonu olumlu veya nötrken Milliyet ve Yeni Şafak'ta olumlu ve nötr tondaki yazıların yanında olumsuz yazılara da yer verildiği görülmüştür. Sözcü'de özellikle MEB'e, EBA içeriklerine ve genel olarak sürecin yönetilmesine karşı olumsuz tonda yazılar öne çıkmaktadır. Yeni Şafak’ta süreç yönetimi açısından YÖK başarılı bulunmuş, "Pandemi döneminin lideri YÖK’tür" başlıklı yazıda pandeminin MEB ve YÖK için bir kriz yönetimi sınavı olduğu belirtilerek iki kurumunda özveriyle çalıştı̆ı belirtilmiş ancak YÖK'ün kriz yönetimi ve proaktifliği öne çıkarılmıştır (Polat, 2020d). Ancak Polat'ın yazılarında uzaktan eğitim altyapısı bulunmayan üniversiteler, eleştirilerin odağında yer almıştır. MEB'in performansı ise yeterince başarılı bulunmamış, mevcut imkanlarını verimli bir şekilde kullanamamaları, vaka sayılarının az olduğu bölgelerde okulların açılmaması, LGS'nin içeriği ve MEB onaylı kursların pandemi sürecinde yüz yüze eğitime devam etmeleri gibi konularda eleştiri almıştır (Polat, 2020b, 2020e, 2020h, 2020i). Milliyet'te de olumsuz yazıların odağında benzer konuların yer aldığı görülmüştür. Köşe yazılarının yayımlanma sıklığı nedeniyle bu konulara daha sık vurgu yapılmıştır.

Uzaktan eğitim sürecinde tartışma konusu olan temel sorunlar arasında sayısı milyonları bulan öğrencilerin uzaktan eğitime katılabilmesi için gerekli olan teknik altyapının mevcudiyeti, sağlıklı bir şekilde kullanılabilmesi, her öğrencinin aynı şartlara sahip olmaması ve neticede dijital teknolojilere ulaşabilmesi noktasında eşitsizliğin ortaya çıkması yer almaktadır. Tüm gazetelerde yer alan köşe yazılarında bu problemlere, değişik oranlarda da olsa değinilmiştir. Öğrencilerin teknik altyapı sorunlarından kaynaklı derslere giriş yapamıyor olmaları ve sosyo-ekonomik durumu iyi olmayan öğrencilerin internet ve teknik malzeme erişim güçlüğü köşe yazılarında ortak sorun olarak karşımıza çıkmışıtır.

Küresel bir problem olan Covid-19 pandemisinde eğitim-öğretim konusunda, diğer ülkelerdeki uygulamaların gözlemlenmesi de önemli bir noktadır. İncelenen tüm haber sitelerinde yer alan köşe yazılarında dünyanın geri kalanında sürecin nasıl yürütüldüğüne kısaca değinilmiştir. Bu değinmeler, ağırlıklı olarak birçok ülkede eğitim-öğretime yüz yüze devam edildiğine ve Türkiye'de de okulların açılması gerekliliğine vurgu yapılması şeklindedir. 
Uzaktan eğitim sürecinde çalışmada yer alan gazetelerin köşe yazılarında baş aktör MEB ve Milli Eğitim Bakanı Prof. Dr. Ziya Selçuk olmuştur. Köşe yazılarının tamamında farklı bakış açılarıyla bu iki aktöre ve açıklamalarına sıklıkla yer verilmiştir. Diğer köşe yazılarından farklı olarak Milliyet'te yer alan köşe yazılarında kurumların ve temsilcilerinin yanında sıklıkla veli, öğretmen ve öğrencilerin de görüşlerine yer verildiği görülmüş̧ür.

Tüm dünyanın neredeyse tek gündemi haline gelen Covid-19 mücadelesinde en çok sıkıntı yaşanan sahalardan birisi eğitim olmuştur. Köşe yazılarında uzaktan eğitim konusunun gündeme gelmesinin beraberinde alışık olmadığımız bir sistemin öğretmen, öğrenci ve veliler üzerindeki psikolojik etkileri de sıklıkla işlenmiştir. Özellikle okul öncesi-ilk-orta dereceli okul çağında olan öğrencilerin evlere kapanma sonucu sosyalleşme ihtiyacını karşılayamadıkları için sosyal ve psikolojik sıkıntılar yaşayabilecekleri çalışma kapsamında yer alan köşe yazılarında dile getirilmiştir. Kapanma sürecinde velilere çocuklarının sosyal ve psikolojik gelişimlerinin olumsuz etkilenmesinin önüne geçilebilmesi adına yapılabilecekler tavsiye niteliğinde köşe yazılarında uzman görüşleri adı altında sıralanmıştır. Bu hususta Abbas Güçlü Milliyet’te yer alan köşe yazılarında diğer gazetelerden farklı olarak veli, öğretmen ve öğrenci talep ve eleştirilerine çokça yer vermiştir. Köşe yazılarında LGS-YKS sınav tarihleri, sınavların hangi koşullarda ve hangi tedbirler doğrultusunda yapılacağı, uzaktan eğitimde işlenen konuların sınavlara dahil edilip edilmeyeceği, sınava girecek öğrencilerin bu süreçte üzerlerinde oluşan stres yükü nasıl hafifletilecek gibi sorulara da cevap aranmıştır.

Uzaktan eğitim sürecinde özel okullar başlı̆̆ına Sabah dışındaki gazetelerin köşe yazılarında yer verilmiştir. Özel okullar başlığının geçtiği köşe yazılarının büyük bir kısmında özel okullarda gerekli tedbirlerin alındığı ve bir an önce okulların açılması gerektiği yönünde dernek başkanlarının açıklamalarına yer verilmiştir. Hürriyet'te 'okul sokaktan güvenlidir' sloganı özel okullarda yayılmaya başladı ifadeleri öne çıkmıştır (Çakmakçı, 2020e). Ayrıca bu süreçte özel okullarda eğitimin uzaktan devam edeceği, bu nedenle ücret iadesinin sadece yemek ve servis ücretlerinde yapılacağı, 2000'e yakın özel okulun kapandığı yönünde köşe yazılarındaki açıklamalar, okulların içinde bulunduğu durumu özetler niteliktedir.

Genel olarak pandemi süreci dolayısıyla eğitimde yaşanan aksaklıkların gelecekte çok daha büyük sorunlara neden olacağı kaygısı tüm yazarlarda görülmektedir. Özellikle Milliyet, Sabah ve Yeni Şafak’taki köşe yazılarındak koşulların düzenlenerek okulların açılması gerekliliğine sık sık vurgu yapılmıştır.

Turkish Academic Research Review - Türk Akademik Araştırmalar Dergisi https://dergipark.org.tr/tr/pub/tarr 
1320 Covid-19 Pandemi Sürecinde Uzaktan Eğitim: Köşe Yazıları Üzerine Bir İnceleme

\section{Kaynakça}

Can, E. (2020). Coronavirüs (Covid-19) pandemisi ve pedagojik yansımaları: Türkiye'de açık ve uzaktan eğitim uygulamaları. Açıöğretim Uygulamaları ve Araştırmaları Dergisi, 6 (2): 11-53. Retrieved from https://dergipark.org.tr/tr/pub/auad/issue/55662/761354.

Çakmakçı, N. (2020a, March 21). İlk teneffüste ziyafet var. Hürriyet. Retrieved from https://www.hurriyet.com.tr/yazarlar/nuran-cakmakci/ilkteneffuste-ziyafet-var-41474161.

Çakmakçı, N. (2020b, April 4). LGS kontenjanı yüzde 50 arttı. Hürriyet. Retrieved from https://www.hurriyet.com.tr/yazarlar/nurancakmakci/lgs-kontenjani-yuzde-50-artti-41486122.

Çakmakçı, N. (2020c, April 19). Pazar günü bile telafi olabilir. Hürriyet. Retrieved from https://www.hurriyet.com.tr/yazarlar/nurancakmakci/pazar-gunu-bile-telafi-olabilir-41497652.

Çakmakç1, N. (2020d, May 23). LGS ve YKS böyle olacak. Hürriyet. Retrieved from https://www.hurriyet.com.tr/yazarlar/nuran-cakmakci/lgs-veyks-boyle-olacak-41523892.

Çakmakçı, N. (2020e, July 25). Doğa Koleji’nde İTÜ’lü Dönem. Hürriyet. Retrieved from https://www.hurriyet.com.tr/yazarlar/nurancakmakci/doga-kolejinde-itulu-donem-41572356.

Çakmakçı, N. (2020f, August 14). Telafisi zor olacak. Hürriyet. Retrieved from https://www.hurriyet.com.tr/yazarlar/nuran-cakmakci/telafisizor-olacak-41586106.

Çakmakçı, N. (2020g, August 15). 21 Eylül'de okullar böyle açılacak. Hürriyet. Retrieved from https://www.hurriyet.com.tr/yazarlar/nurancakmakci/21-eylulde-okullar-boyle-acilacak-41587597.

Çakmakçı, N. (2020h, September 26). 'Çalıkuşu'nun Şirinler Sınıfi'. Hürriyet. Retrieved from https://www.hurriyet.com.tr/yazarlar/nurancakmakci/calikusunun-sirinler-sinifi-41621008.

Çakmakçı, N. (2020i, November 28). Evdeki çocuklar için adım adım kayg1 azaltma rehberi. Hürriyet. Retrieved from 
https://www.hurriyet.com.tr/yazarlar/nuran-cakmakci/evdeki-cocuklar-icinadim-adim-kaygi-azaltma-rehberi-41674271.

Devlet Planlama Teşkilatı. (2006, July 28). Bilgi toplumu stratejisi (2006-2010). Retrieved from http://www.bilgitoplumu.gov.tr/wpcontent/uploads/2014/04/Bilgi_Toplumu_Strateji 2006-2010.pdf.

Güçlü, A. (2020a, April 7). Eğitimi unutursanız, 50 milyonu unutursunuz! Milliyet. Retrieved from https://www.milliyet.com.tr/yazarlar/abbas-guclu/egitimi-unutursaniz-50milyonu-unutursunuz-6182789.

Güçlü, A. (2020b, April 19). Okullar, yaşlılar ve pilot uygulama. Milliyet. Retrieved from https://www.milliyet.com.tr/yazarlar/abbasguclu/okullar-yaslilar-ve-pilot-uygulama-6191978.

Güçlü, A. (2020c, May 5). Attığımız taş ürküttüğümüz kurbağaya değecek mi?.. $\quad$ Milliyet. $\quad$ Retrieved from https://www.milliyet.com.tr/yazarlar/abbas-guclu/attigimiz-tas-urkuttugumuzkurbagaya-degecek-mi-6205360.

Güçlü, A. (2020d, May 10). Korona sınavı! Milliyet. Retrieved from https://www.milliyet.com.tr/yazarlar/abbas-guclu/korona-sinavi-6208965.

Güçlü, A. (2020e, May 20). Karnesiz kapanış, törensiz mezuniyet. Milliyet. Retrieved from https://www.milliyet.com.tr/yazarlar/abbasguclu/karnesiz-kapanis-torensiz-mezuniyet-6215959.

Güçlü, A. (2020f, May 30). Sınav için değil, yaşam için eğitim! Milliyet. Retrieved from https:/www.milliyet.com.tr/yazarlar/abbasguclu/sinav-icin-degil-yasam-icin-egitim-6222634.

Güçlü, A. (2020g, June 3). Zor sorular? Milliyet. Retrieved from https://www.milliyet.com.tr/yazarlar/abbas-guclu/zor-sorular-6225772.

Güçlü, A. (2020h, June 25). Üniversite sinav maratonu başliyor. Milliyet. Retrieved from https://www.milliyet.com.tr/yazarlar/abbasguclu/universite-sinav-maratonu-basliyor-6243605.

Güçlü, A. (2020i, July 4). Kolejler, uzaktan eğitim ve formasyon? Milliyet. Retrieved from https://www.milliyet.com.tr/yazarlar/abbasguclu/kolejler-uzaktan-egitim-ve-formasyon-6251067.

Turkish Academic Research Review - Türk Akademik Araştırmalar Dergisi https://dergipark.org.tr/tr/pub/tarr 
1322 Covid-19 Pandemi Sürecinde Uzaktan Eğitim: Köşe Yazıları Üzerine Bir İnceleme

Güçlü, A. (2020j, July 5). Yeni öğretim y1lı AÖF ve ÖSYM! Milliyet. Retrieved from https://www.milliyet.com.tr/yazarlar/abbas-guclu/yeni-ogretimyili-aof-ve-osym-6251666.

Güçlü, A. (2020k, July 12). Diyelim ki açıldı, diyelim ki açılmadı? Milliyet. Retrieved from https://www.milliyet.com.tr/yazarlar/abbasguclu/diyelim-ki-acildi-diyelim-ki-acilmadi-6257303.

Güçlü, A. (20201, August 12). Uzaktan eğitimde neler olacak? Milliyet. Retrieved from https://www.milliyet.com.tr/yazarlar/abbas-guclu/uzaktanegitimde-neler-olacak-6279953.

Güçlü, A. (2020m, August 15). Yeni öğretim yılına ne kadar hazırız?... Milliyet. Retrieved from https://www.milliyet.com.tr/yazarlar/abbas-guclu/yeniogretim-yilina-ne-kadar-haziriz-6282361.

Güçlü, A. (2020n, August 16). Sezon bitti mi yoksa daha yeni mi başliyor? Milliyet (16.08.2020). Retrieved from https://www.milliyet.com.tr/yazarlar/abbas-guclu/sezon-bitti-mi-yoksa-dahayeni-mi-basliyor-6282836.

Güçlü, A. (2020o, August 18). 17 Ağustos’tan ders aldık mı? Milliyet. Retrieved from https://www.milliyet.com.tr/yazarlar/abbas-guclu/17-agustostanders-aldik-mi-6284213.

Güçlü, A. (2020p August 23). Kolejler bindikleri dalı kesmedi! Milliyet. Retrieved from https://www.milliyet.com.tr/yazarlar/abbas-guclu/kolejlerbindikleri-dali-kesmedi-6288083.

Güçlü, A. (2020r, September 2). Öğrenim ücretleri, dolmayan kontenjanlar ve ek atama?... Milliyet. Retrieved from https://www.milliyet.com.tr/yazarlar/abbas-guclu/ogrenim-ucretleri-dolmayankontenjanlar-ve-ek-atama-6295492.

Güçlü, A. (2020s, September 4). KPSS dayatması, YÖK ve üniversiteler? Milliyet. Retrieved from https://www.milliyet.com.tr/yazarlar/abbas-guclu/kpss-dayatmasi-yok-veuniversiteler-6297467. 
Güçlü, A. (2020t, September 11). Bu gidişle okullar zor aç1lır. Milliyet. Retrieved from https:/www.milliyet.com.tr/yazarlar/abbas-guclu/bu-gidisleokullar-zor-acilir-6303622.

Güçlü, A. (2020u, October 7). Okula gönderme isteğe bağlı olacak. Milliyet. Retrieved from https://www.milliyet.com.tr/yazarlar/abbasguclu/okula-gonderme-istege-bagli-olacak-6323747.

Güçlü, A. (2020v, November 20). Ekran bıkkınlığı. Milliyet. Retrieved from https://www.milliyet.com.tr/yazarlar/abbas-guclu/ekran-bikkinligi6359286.

Güçlü, A. (2020y, December 4). Bugünler de geçecek! Milliyet. Retrieved from https://www.milliyet.com.tr/yazarlar/abbas-guclu/bugunler-degececek-6370859.

Güçlü, A. (2020z, December 13). Hayat için eğitim! Milliyet. Retrieved from https://www.milliyet.com.tr/yazarlar/abbas-guclu/hayat-icin-egitim6378333.

Gürsoy, S. (2020a, April 1). Koronavirüsün psikolojik etkileri. Sabah. Retrieved from https://www.sabah.com.tr/yazarlar/gursoy/2020/04/01/koronavirusun-psikolojiketkileri.

Gürsoy, S. (2020b, April 29). Uzaktan eğitime yakın takip. Sabah. Retrieved from https:/www.sabah.com.tr/yazarlar/gursoy/2020/04/29/uzaktanegitime-yakindan-takip.

Gürsoy, S. (2020c, May 6). Okul öncesi ve koronavirüs. Sabah. Retrieved from https:/www.sabah.com.tr/yazarlar/gursoy/2020/05/06/okuloncesi-ve-koronavirus.

Gürsoy, S. (2020d, May 20). Ortaokul ve koronavirüs. Sabah. Retrieved from https://www.sabah.com.tr/yazarlar/gursoy/2020/05/20/ortaokul-vekoronavirus.

Gürsoy, S. (2020e, June 3). LGS'ye 15 gün kala. Sabah. Retrieved from https://www.sabah.com.tr/yazarlar/gursoy/2020/06/03/lgsye-15-gun-kala. 
1324 Covid-19 Pandemi Sürecinde Uzaktan Eğitim: Köşe Yazıları Üzerine Bir İnceleme

Gürsoy, S. (2020f, September 9). Uzaktan eğitim ve ekonomi. Sabah. Retrieved from https:/www.sabah.com.tr/yazarlar/gursoy/2020/09/09/uzaktanegitim-ve-ekonomi.

Gürsoy, S. (2020g, December 30). Kovid-19 gölgesinde OBP. Sabah. Retrieved from https://www.sabah.com.tr/yazarlar/gursoy/2020/12/30/kovid-19golgesinde-obp.

Millî Eğitim Bakanlı̆̆ı. (2020a, March 12). Bakan Selçuk, Koronavirüs'e karşı eğitim alanında alınan tedbirleri açıkladı. Retrieved from https://www.meb.gov.tr/bakan-selcuk-koronaviruse-karsi-egitim-alanindaalinan-tedbirleri-acikladi/haber/20497/tr.

Millî Eğitim Bakanlığı. (2020b, March 19). Bakan Selçuk, 23 Mart'ta başlayacak uzaktan eğitime ilişkin detayları anlattı. Retrieved from https://www.meb.gov.tr/bakan-selcuk-23-martta-baslayacak-uzaktan-egitimeiliskin-detaylari-anlatti/haber/20554/tr.

Millî Eğitim Bakanlığı. (2020c, March 25). Uzaktan eğitim 30 Nisan'a kadar devam edecek. Retrieved from https://www.meb.gov.tr/uzaktan-egitim30-nisana-kadar-devam-edecek/haber/20585/tr.

Millî Eğitim Bakanlığı. (2020d, March 29). EBA’da canlı sınıfla eğitim başlıyor. Retrieved from https://www.meb.gov.tr/ebada-canli-sinifla-egitimbasliyor/haber/20602/tr.

Millî Eğitim Bakanlı̆̆ı. (2020e, April 1). Türkiye, koronavirüs salgınında ulusal çapta uzaktan eğitim veren 2 ülkeden biri. Retrieved from https://www.meb.gov.tr/turkiye-koronavirus-salgininda-ulusal-capta-uzaktanegitim-veren-2-ulkeden-biri/haber/20618/tr.

Millî Eğitim Bakanlığı. (2020f, April 6). Uzaktan eğitimde "Veli Kuşağı"nı Ziya Öğretmen başlatıyor. Retrieved from https://www.meb.gov.tr/uzaktan-egitimde-veli-kusagini-ziya-ogretmenbaslatiyor/haber/20650/tr.

Millî Eğitim Bakanlığı. (2020g, April 10). Koronavirüs ile mücadelede gençler için "Psikolojik Destek" rehberi. Retrieved from https://www.meb.gov.tr/koronavirus-ile-mucadelede-gencler-icin-psikolojikdestek-rehberi/haber/20677/tr. 
Millî Eğitim Bakanlığı. (2020h, April 29). Uzaktan eğitim 31 Mayıs’a kadar devam edecek. Retrieved from https://www.meb.gov.tr/uzaktan-egitim31-mayisa-kadar-devam-edecek/haber/20803/tr.

Millî Eğitim Bakanlığı. (2020i, May 2). "EBA Asistan” uzaktan eğitimde cevapsız soru birakmayacak. Retrieved from https://www.meb.gov.tr/eba-asistan-uzaktan-egitimde-cevapsiz-sorubirakmayacak/haber/20829/tr.

Millî Eğitim Bakanlığı. (2020j, May 31). Teknolojinin doğru kullanımı için ailelere yönelik iki yeni kılavuz. Retrieved from https://www.meb.gov.tr/teknolojinin-dogru-kullanimi-icin-ailelere-yonelik-ikiyeni-kilavuz/haber/21018/tr.

Millî Eğitim Bakanlığı. (2020k, August 12). Okulları birlikte açacağız. Retrieved from $\quad$ https://www.meb.gov.tr/okullari-birlikteacacagiz/haber/21424/tr.

Millî Eğitim Bakanlığı. (20201, September 2). "EBA Destek Noktaları" uzaktan eğitime erişimin önündeki engelleri kaldırıyor. Retrieved from https://www.meb.gov.tr/eba-destek-noktalari-uzaktan-egitime-erisiminonundeki-engelleri-kaldiriyor/haber/21553/tr.

Millî Eğitim Bakanlığı. (2020m, September 11). Okul öncesi eğitim ve 1. sınıflar yüz yüze eğitime başlıyor. (11.09.2020). Retrieved from https://www.meb.gov.tr/okul-oncesi-egitim-ve-1-siniflar-yuz-yuze-egitimebasliyor/haber/21614/tr.

Millî Eğitim Bakanlığı. (2020n, October 8). Okullarda yüz yüze eğitimde ikinci aşama 12 Ekim Pazartesi günü başlıyor. Retrieved from https://www.meb.gov.tr/okullarda-yuz-yuze-egitimde-ikinci-asama-12-ekimpazartesi-gunu-basliyor/haber/21776/tr.

Millî Eğitim Bakanlığı. (2020o, October 23). Okullarda yüz yüze eğitimde üçüncü aşama 2 kasım pazartesi günü başlıyor. Retrieved from https://www.meb.gov.tr/okullarda-yuz-yuze-egitimde-ucuncu-asama-2-kasimpazartesi-gunu-basliyor/haber/21861/tr.

Turkish Academic Research Review - Türk Akademik Araştırmalar Dergisi https://dergipark.org.tr/tr/pub/tarr 
1326 Covid-19 Pandemi Sürecinde Uzaktan Eğitim: Köşe Yazıları Üzerine Bir İnceleme

Millî Eğitim Bakanlığı. (2020p, November 18). Uzaktan eğitim sürecinin detayları. Retrieved from https://www.meb.gov.tr/uzaktan-egitimsurecinin-detaylari/haber/21990/tr.

Millî Eğitim Bakanlığı. (2020r, December 18). Basın açıklaması. Retrieved from https://www.meb.gov.tr/basin-aciklamasi/haber/22189/tr.

Millî Eğitim Bakanlığı. (2021a, February 4). İlk ve ortaokullarda yüz yüze eğitimin usul ve esasları. Retrieved from https://www.meb.gov.tr/ilk-veortaokullarda-yuz-yuze-egitimin-usul-ve-esaslari/haber/22479/tr.

Millî Eğitim Bakanlığı. (2021b, February 12). Liselerde yüz yüze ve uzaktan eğitime ilişkin usul ve esaslar belirlendi. Retrieved from https://www.meb.gov.tr/liselerde-yuz-yuze-ve-uzaktan-egitime-iliskin-usul-veesaslar-belirlendi/haber/22545/tr.

Millî Eğitim Bakanlığı. (2021c, March 3). İlkokul, ortaokul ve liselerde yüz yüze eğitim detayları belirlendi. Retrieved from https://www.meb.gov.tr/ilkokul-ortaokul-ve-liselerde-yuz-yuze-egitim-detaylaribelirlendi/haber/22672/tr.

Millî Eğitim Bakanlığı. (2021d, April 14). Yüz yüze eğitime verdiğimiz $\mathrm{bu}$ aranın son olmasını yürekten diliyorum. Retrieved from https://www.meb.gov.tr/yuz-yuze-egitime-verdigimiz-bu-aranin-son-olmasiniyurekten-diliyorum/haber/23012/tr.

Millî Eğitim Bakanlığı. (2021e, April 15). Tablet bilgisayar desteğinin 12. fazında, 42 bin 873 tablet daha 62 ildeki öğrencilerimize ulaşıyor. Retrieved from https://www.meb.gov.tr/tablet-bilgisayar-desteginin-12-fazinda-42-bin873-tablet-daha-62-ildeki-ogrencilerimize-ulasiyor/haber/23030/tr.

Millî Eğitim Bakanlığ1. (2021f, May 1). Covid-19. Retrieved from http://covid19.meb.gov.tr/.

Millî Eğitim Bakanlığı. (2021g, May 1). EBA destek noktası. Retrieved from http://ebadesteknoktasi.meb.gov.tr/.

Millî Eğitim Bakanlığı. (2021h, May 1). İnternet paketi desteği. Retrieved from http://covid19.meb.gov.tr/covid19.html?catNo=16.

Polat, T. (2020a, April 2). BÖTE ve Eğitim. Yeni Şafak. Retrieved from https://www.yenisafak.com/yazarlar/turgay-polat/bote-ve-egitim-2054722. 
Polat, T. (2020b, April 9). Bu yıl için baraj sıra uygulamasını kaldırın. Yeni Şafak. Retrieved from https://www.yenisafak.com/yazarlar/turgay-polat/buyil-icin-baraj-sira-uygulamasini-kaldirin-2054787.

Polat, T. (2020c, April 16). Uzaktan eğitim sorunu ve sinavlar. Yeni Şafak. Retrieved from https://www.yenisafak.com/yazarlar/turgaypolat/uzaktan-egitim-sorunu-ve-sinavlar-2054856.

Polat, T. (2020d, June 4). Pandemi döneminin lideri YÖK'tür. Yeni Şafak. Retrieved from https://www.yenisafak.com/yazarlar/turgaypolat/pandemi-doneminin-lideri-yoktur-2055291.

Polat, T. (2020e, August 14). Okullar Neden Açılmıyor. Yeni Şafak. Retrieved from https://www.yenisafak.com/yazarlar/turgay-polat/okullar-nedenacilmiyor-2055945.

Polat, T. (2020f, August 20). Her koşulda öncelikli konumuz eğitimdir. Yeni Şafak. Retrieved from https://www.yenisafak.com/yazarlar/turgaypolat/her-kosulda-oncelikli-konumuz-egitimdir-2055999.

Polat, T. (2020g, September 10). Dünya okulları açarken biz neden korkuyoruz. Yeni Şafak. Retrieved from https://www.yenisafak.com/yazarlar/turgay-polat/dunya-okullari-acarken-bizneden-korkuyoruz-2056187.

Polat, T. (2020h, December 3). Bu Y1l LGS ve YKS Eskisi Gibi $\begin{array}{lllll}\text { Olmamal. } & \text { Yeni } & \text { Şafak. } & \text { Retrieved }\end{array}$ https://www.yenisafak.com/yazarlar/turgay-polat/bu-yil-lgs-ve-yks-eskisi-gibiolmamali-2056960.

Polat, T. (2020i, December 17). Okullar kapalı kurslar açık. Yeni Şafak (17.12.2020). Retrieved from https://www.yenisafak.com/yazarlar/turgaypolat/okullar-kapali-kurslar-acik-2057090.

Porta, M. (2001). A Dictionary of Epidemiology (4th ed.). New York, USA: Oxford University Press.

Sağlık Bakanlığı, Covid-19 Bilgilendirme Platformu. (2020a, July 2). Yayınlar, Covid-19 sözlüğü. Retrieved from https://covid19.saglik.gov.tr/TR66494/pandemi.html. 
1328 Covid-19 Pandemi Sürecinde Uzaktan Eğitim: Köşe Yazıları Üzerine Bir İnceleme

Sağlık Bakanlı̆̆1, Covid-19 Bilgilendirme Platformu. (2020b, July 20). Covid-19 nedir? Retrieved from https://covid19.saglik.gov.tr/TR-66300/covid19-nedir-.html.

Sağlık Bakanlığı, Covid-19 Bilgilendirme Platformu. (2021a, May 1). Retrieved from https://covid19.saglik.gov.tr/.

Sağlık Bakanlığı, Covid-19 Bilgilendirme Platformu. (2021b, May 2). Genel koronavirüs Tablosu. Retrieved from https://covid19.saglik.gov.tr/TR66935/genel-koronavirus-tablosu.html.

Türk Dil Kurumu. (2021, March 5). Güncel Türkçe sözlük. Retrieved from https://sozluk.gov.tr/.

Türkdoğan, O., \& Gökçe, O. (2015). Sosyal Bilimlerde Araştırma Yöntemleri. Konya, Turkey: Çizgi Kitabevi.

Uçar, S. (2020a, July 10). Kolejler batarken tarikatlar çıkacak! Sözcü. Retrieved from https://www.sozcu.com.tr/2020/yazarlar/sultan-ucar/kolejlerbatarken-tarikatlar-cikacak-5922042/.

Uçar, S. (2020b, December 4). Gıda mühendisi yok! Veteriner olur mu? Sözcü. Retrieved from https://www.sozcu.com.tr/2020/yazarlar/sultan-ucar/gidamuhendisi-yok-veteriner-olur-mu-6152739/.

Ünalan, D . (2021). Gazeteciliğin dönüşümü: Habertürk, Sözcü ve Yeni Şafak gazetelerinin sosyal medya haberciliği çerçevesinde incelenmesi. Selçuk İletişim, 14 (2), 952-981. DOI: https://doi.org/10.18094/josc.862047.

World Health Organization. (2020, March 11). WHO Director-General's opening remarks at the media briefing on COVID-19 - 11 March 2020. Retrieved from https:/www.who.int/director-general/speeches/detail/whodirector-general-s-opening-remarks-at-the-media-briefing-on-covid-19---11march-2020.

World Health Organization. (2021a, May 2). WHO Coronavirus (COVID-19) Dashboard. Retrieved from https://covid19.who.int/.

World Health Organization. (2021b, May 5). Coronavirus prevention. Retrieved from https://www.who.int/health-topics/coronavirus\#tab=tab 2. 
Yıldırım, B. (2015). İçerik Çözümlemesi Yönteminin Tarihsel Gelişimi Uygulama Alanları ve Aşamaları. B. Yıldırım (Ed.). Iletiş̧im Araştırmalarında Yöntemler Uygulama ve Örneklerle içinde (s. 105-153). Konya, Turkey: Literatürk Academia Yayınları.

Yükseköğretim Kurulu. (2020a, March 13). Koronavirüs (Covid-19) bilgilendirme notu: $1 . \quad$ Retrieved from https://www.yok.gov.tr/Sayfalar/Haberler/2020/coronavirus bilgilendirme 1.as px.

Yükseköğretim Kurulu. (2020b, March 18). Basın aç1klaması. Retrieved from $\quad$ https://www.yok.gov.tr/Sayfalar/Haberler/2020/universitelerdeuygulanacak-uzaktan-egitime-iliskin-aciklama.aspx.

Yükseköğretim Kurulu. (2020c, March 23). YÖK dersleri platformu (Yükseköğretim kurumları dersleri). $\quad$ Retrieved from https://yokdersleri.yok.gov.tr/.

Yükseköğretim Kurulu. (2020d, March 23). "YÖK dersleri platformu" öğrencilerin erişimine açıldı $\quad$ Retrieved from https://www.yok.gov.tr/HaberBelgeleri/BasinDuyurusu/2020/yok-dersleriplatformu-erisime-acildi.pdf.

Yükseköğretim Kurulu. (2020e, March 26). Basın açıklaması. Retrieved from

https://www.yok.gov.tr/Sayfalar/Haberler/2020/YKS\%20Ertelenmesi\%20Bas\% C4\%B1n\%20A\%C3\%A7\%C4\%B1klamas\%C4\%B1.aspx.

Yükseköğretim Kurulu. (2020f, April 29). Üniversite öğrencilerine ücretsiz 6 GB'lı "uzaktan eğitime destek" kotası. Retrieved from https://www.yok.gov.tr/Sayfalar/Haberler/2020/ogrencilere-egitime-destekkotasi.aspx.

Yükseköğretim Kurulu. (2020g, May 8). Covid-19 bilgilendirme. Retrieved from https://covid19.yok.gov.tr/.

Yükseköğretim Kurulu. (2020h, August 13). Yükseköğretim kurumlarımızdaki 2020-2021 eğitim ve öğretim dönemine yönelik açılama. Retrieved from https://www.yok.gov.tr/HaberBelgeleri/BasinAciklamasi/2020/2020_2021_akad emik_yili_baslangici_aciklama.pdf.

Turkish Academic Research Review - Türk Akademik Araştırmalar Dergisi https://dergipark.org.tr/tr/pub/tarr 